\title{
ACADEMIC STUDY PROGRAMS AND EDUCATION FOR THE PROFESSION OF SPORTS, SPORTS COACH OCCUPATION
}

\author{
PROGRAMAS ACADÉMICOS DE ESTUDIOS Y DE ADIESTRAMIENTO \\ PARA LA PROFESIÓN DE DEPORTE, \\ OFICIO ENTRENADOR DEPORTIVO
}

\author{
Jaroslava Radojević, Miljan Grbović, Branislav Jevtić \\ Faculty of Sport and Physical Education, University of Belgrade, Serbia
}

\begin{abstract}
This paper was made on the basis of three cognitive steps of inductive and deductive reasoning in order to confirm the status of sport as a significant factor of the social reality in this century, to identify problems in the field of sports profession and occupations and to propose measures and activities which would set up a logical strategic baseline for defining the criteria when formulating the profession and determining sports occupations. Within the first cognitive step, the views on the mission of sports, which has been assessed to be of an immediate and utmost importance for complementing ontological and body-related study on sports in this century, have been pointed out. Within the second step, the causes leading to the fact that the profession of Sports and sports occupations are inadequately recognized, both at the national and international level, have been considered. The problems observed in the area of the academic study programs at the faculties in Serbia were analysed and correlated with the trends in education (education and training) for the sports coach occupation. Within the third step, the elements of the affirmation strategy for the profession of Sports have been proposed. The purpose of this paper should be understood as a step further in the civilization's confirmation of the importance and role of sports, as well as in providing a framework for strategic actions for the benefit of the profession, as well as the existing and new occupations in sports. In this paper, it was equally important to identify and point out the barriers found in the academic programs of Serbian faculties that need to be overcome in order to achieve the desired affirmation and progress of Physical Education and Sport Science.
\end{abstract}

Key words: SPORTS/ PROFESSION / OCCUPATIONS / SPORTS COACH /UNIVERSITY THIRD MISSION / STUDY PROGRAMS / SERBIA

\begin{abstract}
EXTRACTO
Este trabajo se hizo sobre la base de tres pasos cognitivos de la forma de conclusión inductiva y deductiva con el fin de confirmar la posición del deporte como un factor importante de la realidad social en este siglo, de detectar problemas en el espacio de la profesión y oficio en el deporte, y de proponer medidas y actividades que establecerían una línea estratégica lógica para determinar los criterios al formular la profesión y determinar los oficios en el deporte. En el primer paso cognitivo se destaca la visión de la misión del deporte que se estima tener una importancia directa y primordial para completar la educación ontológica y teleológica sobre el deporte en este siglo. En el segundo paso se observaron las razones que tanto en el nivel nacional, como también en el internacional conducen hasta que la profesión Deporte y oficios en el deporte no se reconocen de manera adecuada. Los problemas notados en el espacio de programas de estudios académicos de las facultades en Serbia, se analizaron y relacionaron con las tendencias en la educación (adiestramiento y formación) para la profesión entrenador de deporte. En el tercer paso se propusieron elementos para la estrategia de afirmación de la profesión Deporte. El objetivo del trabajo debe entenderse como un paso más en la continuación de la confirmación civilizacional de la importancia del papel de deporte, como también en el aseguramiento de marcos para la actividad estratégica a favor de la profesión, y de los oficios en el deporte, existentes y nuevos. De igual importancia era identificar y destacar, en el presente trabajo, las barreras en los programas académicos de las facultades serbias que deben superarse si se quiere la afirmación y progreso de la Ciencia de la educación física y el deporte.
\end{abstract}

Palabras claves: DEPORTE / PROFESIÓN / OFICIO / ENTRENADOR DEPORTIVO / TERCERA MISIÓN DE LA UNIVERSIDAD / PROGRAMAS DE ESTUDIOS / SERBIA 


\section{SPORT IN LINE WITH THE BEING AND NEEDS OF A MODERN SOCIETY}

The approach that affirms the values of sport in the function of developing an individual and society in the $21^{\text {st }}$ century is followed by the leading international sports organizations, as well as world and continental sports organizations. A similar, if not identical approach to the place and the role of sport in the $21^{\text {st }}$ century is recognized in the documents and resolutions of political organizations (continental and intercontinental). Thus, the United Nations Declaration and Recommendations from Magglingen "Creating a Better World Through Sport" (2003) affirms the values of sport important for the physical and mental health of the individual, the healthy growth of students through sports and physical education, the construction of quality relationships in the society, the progress of the local community, numerous social and cultural barriers. This document contains messages about a doping-free sport, filled with honesty with each and every member of the sport and society ... as well as many other things. Since 2008, the United Nations Sport Office has promoted sport as a means of developing peace in accordance with the Millennium Goals adopted. Within this office, there are sectors in charge of thematic areas: Sport and Health, Sport and Gender Equality, Sports and Development of Children and Youth, Sport for Persons with Disabilities, Sport and Peace.

The world's leading sports organization, the International Olympic Committee (IOC), lists documents and activities in line with its mission and agenda for the development of the sport movement (www.ioc. com). The analysis of these documents leads to the conclusion that there is a need to constantly overcome the role and mission of the IOC, which is also taking place through the dynamics of upgrading attitudes about the contemporary sport, that is, through programs that seek answers to:

1. Challenges of the IOC and the entire sport movement on the place and role of sports in cultural (civilization) development, the promotion of sport in society, and the preservation of its legacy;

2. Issues relevant to the impact of sports in creating an "active society", the participation of women, children and the elderly in sports ...;
3. Tendencies in expanding the capacity of sports in education of young people and acquiring business skills for the 21 st century, as well as in the importance of sports to the development of the local community;

4. Concerns about sports and professional career of athletes.

The Charter of the Council of Europe defines that sport is any form of physical activity that, through organized participation or independently, aims to express and improve the physical fitness and mental health of an individual, builds and nurtures social relationships, and makes achievements in competitions at all levels. In this regard, the participation of as many citizens of both genders as possible, all ages, work and health status, achievement of personal, national and elite results can be defined as the objective of the sport of each member of the Council of Europe (CE).

By issuing the White Paper, supplemented by the "Lisbon Treaty" (2009), the European Union seeks to promote and develop its members through sport. These two documents emphasize the specifics of sport as "conditio sine qua non" in the modern society. The specificities of sport are defined and realized through two levels: the first, which respects the specificity of sports activities and sports rules (guaranteed uncertainty of competition, competition and category ...) and the other, which contains steps that ensures respect and nurture the specificity of the structure and the autonomy of sports, its pyramidal organization and solidarity in sports ... (Chappelet, 2010).

Sport is also seriously addressed in the White Paper on EU Intercultural Dialogue (2008), which recognizes and highlights its educational and educational effects and their importance for intercultural dialogue and comprehensive integration (Guide to EU sport policy, 2011).

In promoting the value of sports, the European Union finances projects that have the significance for further development and affirmation of the values of sports, such as inclusion, social dialogue, volunteerism, career after sports, the environment ... It also realizes its political and economic goals in the overall European development through programs "Youth in Action", "Lifelong Learning", "Europe for Citizens", "Health Programs". In addition to these, research teams from sports are accessible science and research funds, as well as funds that finance the development of European regions. The "DAPHNE" program is also 
open to sport and is aimed at preventing discrimination and abuse of children, young people and women.

Sport in the function of the development of the individual, collectives and society, as well as its economic capacity (sport as industry), were an incentive for the legal regulation of its heritage and activities. Over time, the strengthening of the EU regulatory function in the areas related to the implementation of sports activities and operations has been registered, and the basis for the gradual emergence and profiling of EU sport law has been created (Šuput, 2015). In keeping with modern trends and studying sports, it has become a kind of social phenomenon. Since sport is a very important factor in social relations, the question arises as to whether the right to sport is a human right (Andonović, 2017). However, a comprehensive view of the question of a man and his sporting being is possible only through a comprehensive, theoretical, methodological and gnoseology-based philosophy of sport, which has been developing as a discipline of philosophy since the 1960s, in order to achieve primacy over this $21^{\text {st }}$ century research of "positive science" (most of the sports sciences) that resists the repeated studies of the already established facts of experimental and laboratory observations of the movement of humanity through sport. The positivistic approach, which excludes the study of the cultural (civilization) context of sports, opposes the philosophy of sport whose "ends" of a cognitive and methodological continuum are determined by the anthropology and phenomenology of sport (Chart 1, Figure v). "The inseparability of these regions can be expressed in the form of a unique question "How practicing sport generates a person" (Koprivica, 2018). Thus, in accordance with the subject of studying this work, it is necessary to answer the question and to highlight how practicing sport generates a person.

Defining and treating the sport in its totality, in the way that is promoted by the most important world organizations and individuals, especially its influence on the being and needs of the contemporary individual and the society, gives the basis and encourages a much more serious approach to this problem and engaging in smaller, even in our academic and sports community.

\section{FRAMEWORK OF INTERPRETATION OF THE MISSION OF MODERN SPORT}

Sport is a specific, autonomous and organized activity that achieves cultural values, democratizes society, raises the quality of life, promotes national identity, cultural diversity ... These statements have not exhausted the quotation of all the values of sports that grow into utilitarianism as an ethical theory that claims that the best action is the one that maximizes the benefit. The utilitarian approach in the understanding of sports emerged on the basis of the analysis of its axiological side, which in the first steps of its creation relied on the romantic values of sport (pride, honour, belonging, self-exaltation, fair play, moral excellence) in order to complement and with the enlightenment values of sport (individualism, universalism, education, competitive context) (Parry, 2009). In the next step, the axiological side, i.e. defining the value of sport, is complemented by a great number of theoretical and empirical facts about the effects of sport on the individual and society.

An individual is stimulated by the spirit of sport, which imposes a sporting activity the body a sporting activity that takes place in accordance with the rules, but also through co-operation, solidarity, achievement. All this leads to self-deception that is in the function of self-limitation ... "as my result, my otherness that came out of me" (Koprivica, 2018). By participating in sports and new experiences, a person changes his character. Through determination, initiative, self-determination, innovation, tolerance of stress, sometimes with a high degree of risk to personal safety and health, many problems of the spiritual, psychomotor, social, fictitious, affective, material, financial ... are resolved. When it comes to society, sport has become a means and place where multi-layers work on the problem of sustainable development, as a balance between the factors of life and socio-economic environment, in the function of the civilization and the future of the planet and its inhabitants.

"Sustainability is the result of the effects of sports on health, the environment, society ... and only 30 minutes of daily physical activity provides significant health and economic benefits. Modern sport, as well 
as the overall physical activity of man is fulfilled by goals; they encourage economic and ecological sustainability, i.e. they affirm the relations that economy requires today, and ecology today and tomorrow (Jevtić, 2010).

Sport is a significant economic category within which almost $3 \%$ of the world's total income is generated, new jobs are created and investments are made. Today, sport is also defined through the definition of its ten basic characteristics in the marketing sense (purchase, acceptance, promotion and media, distribution, product, price, facilities, competition, exchange and employees).

Smith and Westerback (2007) have established a "strong communication power" of physical activity through which it is possible to reach each member of the community, which has the effect that physical activity is cited as the first tool in the "appeal to the young" for their growing up in family, sports, education, culture, community (practitioners, participants, "fans"). "Positive influence on health" is an ideal platform for awareness of the benefits of physical activity for the health of each member of the community, as well as an incentive for concrete activity. The following are the factors of physical activity that, among other things, stimulate: "community interaction" both in functional sense and in democratization; a desire for peace, social cohesion, joy ...; "Awareness of sustainability" and zero tolerance for environmental degradation; "Cultural identification and integration" and "Immediate welfare from satisfaction" which as such inspires members of the community to practice, support and highly value physical activity.

It can be concluded that the new millennium affirms sport and sports movement as a cultural (civilization) and value that brings many good things to the individual and society that nourishes, organizes, improves, celebrates it.... (Jevtić, Radojević, 2011). Sport has become an organized activity that affirms personal, sports, social and ethnic values. It democratizes society, raises quality of life, strengthens health, and promotes national identity. Sport is an activity that solves issues of social exclusion, youth delinquency, fragmentation of the community, and societies "are struggling" with the effects of disrupted health, shortening the working and life expectancy of a man (Radojević, Jevtić, 2011). Today, as it is more than ever before, there is a need to strengthen the values of the society, such as effort, respect, solidarity, trust, coexistence, social cohesion, ethnic, gender and religious tolerance ... Sport has become a powerful means to that goal, to "healing of the society" (Jevtić, 2018), because sport is in the most direct way comfortable with the spirit of modern times, which, among other things, is reflected in the imperative of continual raising opportunities in all sectors of social reality" (Koprivica, 2018).

During the $21^{\text {st }}$ century sport will be explored intensively and multidisciplinary, to a significant extent, especially in the area of social sciences. In that respect, education of sports professionals shall get both a new function and a dimension that is different from that one of the last century (Sheridan, 2014) because sport acts both on the morale and on the physical side of the athlete, i.e. with the training, both character and will are developing, in a word, through a sport a man is created" (Durantez, Perez-Turpin, Vidal, Pandoro, Patino, Molina, 2010). In accordance with the subject, goal and previous discussions in this paper, it could be concluded that the academic study programs of sports should be directed towards education of young professionals, to sustainably promote personal and social values of sport through their profession, interests, innovations and new jobs.

\section{SPORT - PROFESSION OF THE $21^{\text {ST }}$ CENTURY}

Long before the accreditation of higher education institutions and their functioning according to the principles of Declaration from Bologna, since 1938, education of professionals in education and sports had been going on in Serbia. At the beginning, these were annual courses for teachers and coaches, with the aim to train personnel to work in the physical exercise area of the widest circle of citizens. These courses served their purpose when the Government of the Federal People's Republic of Yugoslavia (1945), with its Decree, began the construction of the first higher education institution in Belgrade, which grew from the State Institute of Physical Education (1947) to the Faculty which was admitted to the membership of the University of Belgrade in 1963. 
In the long period of time, from 1945 to 2000, higher education institutions in Serbia functioned as state faculties with the aim of educating professionals for the occupation of a teacher of physical education with occasional directives for work in certain sports or recreation. Such educated professionals were accepted and appreciated in sports. Of course, the time that was behind us had a different attitude and access to the needs of society and its development through sport from today. Thus, the professionals who were educated for education and without a high specialization in the training and competing methodology and technology, were the bearers of most professional activities within the sports system. These professionals were the bearers of children's and school sports, the development strategies of young athletes and their training to the top and elite results. There was no division into private and commercial sports in the sports system of these days, there was no professionalization, commercialization and globalization of sports of today. Sport was a national heritage!

In the period from 2000, the issue of profession and occupation in sport was sporadically opened. The most frequent reason was the adoption of documents which would closer determine occupations in sports. (In order to be determined more closely, these documents are brought at the level of the state body in charge of sports in the Republic of Serbia). However, needs to recognize the profession, users, working conditions, modernization and modernity of certain sports remained unnoticed, or better to say neglected ... as well as significant international initiatives that aim to have the quality of sports services, and therefore professionals and programs in sport. Thus, the Magglingen Declaration (2000), which contains ten recommendations for the work of a sports coach, re- mained unnoticed. The first of these recommendations refers to ethical behaviour and the mechanism for monitoring the ethical approach in the work of coaches. There followed: systematization of the competence of coaches; education and training in accordance with the needs of athletes and sports; place and role of coaches in the development of athletes of all levels. A significant part is related to lifelong learning, the training of coaches in relation to free access and the dynamics of education in accordance with the obligations in coaching. An integral part of the Magglingen Declaration is an attempt to define Sport's profession and to cover contemporary and well-established professions over it, primarily the profession of a sports coach. Sociologists believe that this part of the declaration is problematic and will be difficult to solve because every profession should contain a meritorious, authoritarian and decisive voice on the issues of the profession, and when it comes to sports it is not so (Malcom, Pimenta, Pinherio, 2013).

\section{The problem of profession and occupation in sports}

The characteristic of sport of the $21^{\text {st }}$ century, both in Europe and in the United States, as well as in most other regions of the world, is, among other things, increased the number of jobs that lead to an increase in the number of occupations that create a "product" that affirms the economic and social value of sports. In addition to traditional occupations, such as sports coaches, sports instructors, managers, doctors, physiotherapists, journalists, sports facilities managers ... new jobs are open in sport and a new social reality and economic value are created (Tables 1 and 2). 
Table 1. Possible jobs and positions in modern sport (Jevtić, 2014)

\begin{tabular}{|c|c|c|c|c|}
\hline $\begin{array}{l}\text { Manufacture of sports } \\
\text { goods }\end{array}$ & $\begin{array}{c}\text { Project Managers, } \\
\text { Programs }\end{array}$ & Publications & Betting houses & $\begin{array}{l}\text { Sports events, } \\
\text { community }\end{array}$ \\
\hline $\begin{array}{l}\text { Production and sale of } \\
\text { equipment, footwear }\end{array}$ & $\begin{array}{c}\text { Consultants, } \\
\text { researchers, public } \\
\text { and national politics, } \\
\text { lobbyists ... }\end{array}$ & $\begin{array}{l}\text { Coaching the individual and } \\
\text { the team }\end{array}$ & $\begin{array}{c}\text { Design and } \\
\text { exploitation of sports } \\
\text { facilities }\end{array}$ & Events in mass sports \\
\hline $\begin{array}{l}\text { Sports marketing, } \\
\text { management and } \\
\text { promotion }\end{array}$ & $\begin{array}{l}\text { Sports Event } \\
\text { Management }\end{array}$ & Fitness equipment and gym & $\begin{array}{l}\text { Sport Photography - } \\
\text { Film }\end{array}$ & $\begin{array}{l}\text { Psychological } \\
\text { preparation and } \\
\text { psychiatry }\end{array}$ \\
\hline Sports medicine & $\begin{array}{c}\text { Management of } \\
\text { volunteers in sports }\end{array}$ & $\begin{array}{l}\text { Web design and social } \\
\text { networks }\end{array}$ & $\begin{array}{l}\text { Sports nutrition and } \\
\text { supplements }\end{array}$ & Accounting \\
\hline Aging and physical activity & Extreme sports & Service equipment & $\begin{array}{l}\text { Information and } \\
\text { sports news }\end{array}$ & Revision \\
\hline Health and Fitness & Sport tourism & Blogs & $\begin{array}{l}\text { Production of trophies } \\
\text { and memorabilia }\end{array}$ & Design \\
\hline Security and safety & Participant-mass sport & $\begin{array}{c}\text { Sale of appliances and } \\
\text { equipment }\end{array}$ & Sport and fun & Insurance and health \\
\hline Commercial sports & Professional sport & $\begin{array}{c}\text { Simulators and software } \\
\text { solutions }\end{array}$ & Information systems & Career athletes \\
\hline $\begin{array}{l}\text { Recreation with physical } \\
\text { activities }\end{array}$ & Sports organization & $\begin{array}{c}\text { Construction and } \\
\text { maintenance of sports } \\
\text { surfaces }\end{array}$ & $\begin{array}{l}\text { TV; internet, radio } \\
\text { channels }\end{array}$ & Projects for the EU \\
\hline
\end{tabular}

The European Commission for the Classification of Economic Activities (NACE) monitors economic activity in the field of sport by analysing two sectors: the sports sector or activities related to exercise, and the sports industry supporting sports activities as their inseparable part.

Table 2. Possible jobs and Employers in sport in Serbia (Jevtić, 2014)

\begin{tabular}{|c|c|c|c|c|}
\hline Public institutions & $\begin{array}{c}\text { Primary and secondary } \\
\text { schools }\end{array}$ & Sports clubs - franchises & $\begin{array}{l}\text { Public and private } \\
\text { spot centers }\end{array}$ & Amateur clubs \\
\hline Government & Faculties and Universities & Sports Federations & $\begin{array}{l}\text { Authorities of the } \\
\text { Province }\end{array}$ & $\begin{array}{l}\text { A wider sports } \\
\text { community }\end{array}$ \\
\hline Schools & $\begin{array}{l}\text { Sports institutes, research } \\
\text { departments }\end{array}$ & $\begin{array}{l}\text { International sports } \\
\text { organizations }\end{array}$ & $\begin{array}{l}\text { National and } \\
\text { international } \\
\text { corporations }\end{array}$ & The media \\
\hline $\begin{array}{l}\text { Amateur and } \\
\text { professional coaches }\end{array}$ & $\begin{array}{l}\text { Commercial parts of sports } \\
\text { federations - League }\end{array}$ & NGO & Affirmed athletes & Professional sport \\
\hline Citizens & $\begin{array}{c}\text { Territorial (sports and other) } \\
\text { organizations }\end{array}$ & National Olympic Committee & IT & Tourism \\
\hline The army & Police & Religious communities & Social policy & Health system \\
\hline $\begin{array}{l}\text { Units of local self- } \\
\text { government }\end{array}$ & WEB and social media & Civil protection & $\begin{array}{l}\text { Design and } \\
\text { construction }\end{array}$ & Private initiative \\
\hline
\end{tabular}

According to Petry at al. (Petry, K., Froberg, K., Madella, A., Tokarski, W., 2008), ten years ago, almost $1 \%$ of UK employees worked in sports and sports related areas, which makes 10.8 employees per 1000 exercisers. This relationship varies within the EU, so in Austria, there are 6 employees per 1000 exercisers, in the Netherlands 5.5, Spain 4.8, and in Germany 4 are employed per 1000 exercisers. It is estimated that there are nearly 300,000 full-time employees in 
the US, and one million full-time sports workers. In other words, the new era affirms a large number of occupations in sports. Sport of the $21^{\text {st }}$ century is oriented towards cultural (civilization) values in the sustainable development of the individual, society and nature. Accordingly, a large number of initiatives are being registered to preserve the cultural heritage of sport and work towards its economic sustainability through entrepreneurial initiatives, innovation and self-employment (Jevtić, 2014).

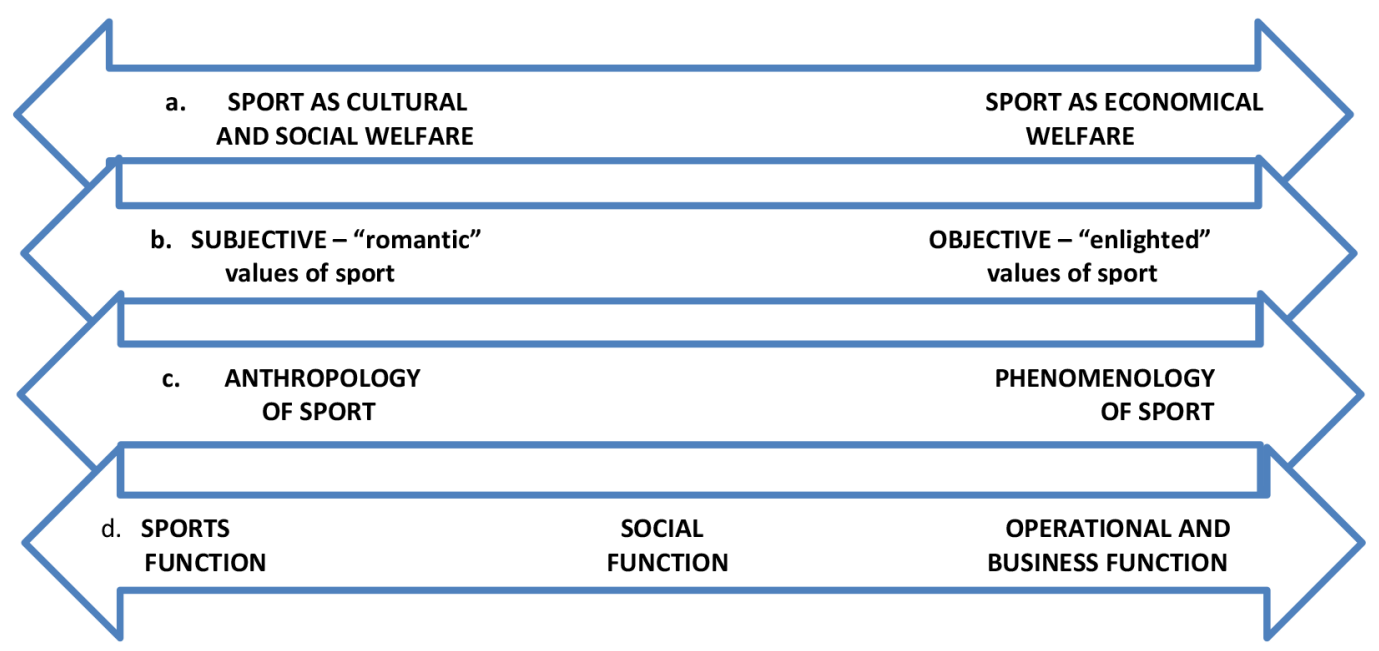

Chart 1. Ontological (a), axiological (b), cognitive (c) and business (d) continuum of sport (Jevtić 2014, 2018)

\section{Education and training for sports coach occupation}

The coach is one of the earliest occupations that originated from the period of ancient civilizations. The development of a modern society has led to the fact that the sports coach occupation becomes the subject of many debates and discussions that have led to the abandonment of the population that it is only about the work of learning motor skills (Gobert, Cote, Mallet, 2006). Today, sports coaches are educated and trained through defined programs for acquiring professional qualifications filled with knowledge, skills and routines for the benefit of athletes-practitioners (sports centre of the system). In other words, in sport, quality management efforts are noticed at all levels of sporting organization. By setting and realizing its mission through quality management models, sport has opted for a fundamental redefinition of its mission and it could be said that it has focused on building its profession. Contrary to the general understanding that the sport profession and profession are a sports coach defined by all known categories, in reality there are many unresolved problems of status and profession and occupation (Duff, Hartley, Bales, Crespo et al., 2011).

Sports coaches work on the basis of a large number of business and highly-skilled knowledge, skills and competences, such as the setting up of the program and solving the dilemma of the training process, planning, observing, monitoring the implementation of the plan, analysing the effects, concluding, and athletes in the training process. Sports coach describes his cognitive, practical, affective and business skills. The coach prioritizes plans and realizes programs that will lead to improved training performance compared to some of the adult, group, health, motor, social, educational attributes of the individual-group-team.

The occupational sports coach has formed around five main roles of coaches: (1) role in training; (2) a specialized role towards athletes' groups (children, disabled, talents...); (3) educational role; (4) leadership role (as a selector or head of the expert professionals), and (5) a compact and complex role in managing the construction of a top-notch sporting result (Dick, 2011). These allegations should also include the roles that the $21^{\text {st }}$ century trainer focuses on innovations in the training process and affirms through entrepreneurial activity both in the economic and social milieu.

Job and licence of a sports coach are preceded by learning based on an extensive list of sources of knowledge from formal, non-formal and informal sources. The interest of the sports coach has become 
unique and in that it meets and balances formal and non-formal education. The step forward of this profession is the informal learning that dominates and which makes the coach more professional, inde- pendent and successful both in training and in the labour market. The efficiency of the sports coach is determined by the individual's disposition for lifelong learning, as illustrated in the figures from Table 3.

Table 3. Types of education and knowledge sources for a sports coach profession (prepared according to: Abraham, Collins, +Martindale, 2006; Lemyre, Trudel, Durand-Bush, 2007; Erickson, Bruner, MacDonald, Côté, 2008; Stoszkowski, Collins, 2015)

\begin{tabular}{|c|c|c|c|c|}
\hline \multicolumn{2}{|c|}{ Formal education } & \multicolumn{3}{|c|}{ Non-formal and informal education } \\
\hline Lectures & Courses & Reflexion & $\begin{array}{l}\text { Observation and analysis of } \\
\text { the competition }\end{array}$ & Professional trips \\
\hline Exercises & Teachers & Conferences & $\begin{array}{l}\text { Observing the work of } \\
\text { other coaches }\end{array}$ & Foreign coaches \\
\hline Practical teaching & $\begin{array}{l}\text { Formal and informal } \\
\text { mentors }\end{array}$ & Congresses & Observing elite athletes & Coaching periodicals \\
\hline $\begin{array}{l}\text { Seminars (as a form of } \\
\text { teaching) }\end{array}$ & Other students & Seminars & Video analysis & Textbook \\
\hline Books and periodicals & Information systems & Courses & Blogs & Mentors, senior coaches, \\
\hline $\begin{array}{l}\text { Complementary } \\
\text { science and areas }\end{array}$ & $\begin{array}{l}\text { Technology of other } \\
\text { sports }\end{array}$ & Clinics & $\begin{array}{l}\text { Internet presentations and } \\
\text { models of learning }\end{array}$ & One to one training \\
\hline \multirow{2}{*}{$\begin{array}{l}\text { Physical education, } \\
\text { customized exercise, } \\
\text { sport in institutions... }\end{array}$} & $\begin{array}{l}\text { Writing projects, final } \\
\text { papers }\end{array}$ & $\begin{array}{l}\text { Leading their athletes - } \\
\text { teams, sparring partner. }\end{array}$ & Information platforms & Sport industry \\
\hline & Management in sport & Other sports & $\begin{array}{l}\text { Planning and realization } \\
\text { of individual and team } \\
\text { training }\end{array}$ & $\begin{array}{l}\text { Other areas of } \\
\text { complementary sports, } \\
\text { training and results }\end{array}$ \\
\hline Thematic workshops & $\begin{array}{l}\text { Educational and sport } \\
\text { strategy }\end{array}$ & $\begin{array}{l}\text { Athletes' parents, } \\
\text { teachers }\end{array}$ & $\begin{array}{l}\text { Certified training programs } \\
\text { of NSF and MSF }\end{array}$ & $\begin{array}{l}\text { Scientists, employees in } \\
\text { sports (selectors, program } \\
\text { managers, analysts, } \\
\text { physiotherapists...) }\end{array}$ \\
\hline Training programs & $\begin{array}{l}\text { Tutors and project } \\
\text { methods and problem } \\
\text { teaching }\end{array}$ & \multicolumn{2}{|l|}{$\begin{array}{l}\text { Experience from sport - } \\
\text { sports }\end{array}$} & $\cdots$ \\
\hline & & & $\mathbf{T}$ & \\
\hline \multicolumn{2}{|c|}{$\begin{array}{l}\text { Learning - the theoretical and conceptual } \\
\text { framework of biomedical, socio-humanistic } \\
\text { and sports science (not about the profession } \\
\text { and occupation of a sports coach) }\end{array}$} & \multicolumn{3}{|c|}{$\begin{array}{l}\text { Learning directed to the work of a sports coach } \\
\text { (knowledge and skills adequate to occupation) }\end{array}$} \\
\hline
\end{tabular}

The acquisition of competence for coaching work should take place through two phases that can be observed separately, but essentially are an integral process. In the first phase, the development and acquisition of the first coaching license is based on the competences for implementing the program in participatory (mass) sports. The second phase is dominated by programs that lead to the creation of com- petence for a superior and elite result. Although this is an integral process, however, these two phases are just template-identical (Vocaport, 2004). Regardless of whether it is a participant or an elite sport, the sports coach profession is predestined for those who are oriented towards lifelong learning, who persist in the proclaimed mission of sports, who are in- 
spired to introduce innovations into the work and the environment of the athlete. The most important information that coaches gain during their education and careers are from the field of specific training methods (with almost 50\% of significance) with topics: how to plan and train; motor learning; communication and performance analysis. Stoszowski and Collins (Stoszowski, Collins, 2015) point out that the coaches are slowly shrinking interest in subjects from science applied in sports (psychology, physiology, biomechanics). They state that the reflection of the acquired, previous sports and trainer experience leads to a decrease in interest in knowledge of techniques and tactics and other knowledge related to the sports branch or the discipline. Sources that coaches value as relevant for further learning are classified in sequence in communication with other coaches, followed by clinics, seminars, conferences, video material analyses, watching competitions (directly on TV), books, magazines, through to transparent and applicative articles in scientific journals. As it is a lifelong learning, it is obvious that, in the most prolific stage of their development, the informal knowledge sources with $93 \%$ representation are dominant in the plan of a comprehensive training program (education and training) of the sports trainer because: "each person acquires and acquires knowledge, skills, forming attitudes from day-to-day experience and through communication with the environment" (an excerpt from the European Qualifications Framework). From science, coaches expect answers to questions about mental training, team building, nutrition, physical preparation, fitness, injury prevention and recovery, as well as answers related to understanding the needs of today's athletes (Stoszowski, Collins, 2015). Therefore, the work of a sports coach should be seen as a complex, dynamic activity and employment based on the context of the profession, as well as the tendencies described by a contemporary professional. It is, like other contemporary occupations, predetermined by the factors of the system of sports, society and technology of the training process (Lyle, 2006). The choice of sports coach profession depends on factors of internal and external motivation, as well as the management of dispositions for its performance. Knowledge and competence in the profession arise as internal, and the workplace and its attributes, as an external factor for the choice of profession and occupation. This means that solving the problems of their profession and professions, coaches and coaching organizations should start from regulating external factors that emerge from the field of technology and methodology of training work and are closely defined by the strategy of overall social development. The external factors also include study programs for sports coach vocational training.

\section{Profession sports: Education and training for the occupation sports coach in Serbia}

During 2018, the National Qualifications Framework was adopted in Serbia for the first time, a document relevant to every profession and a guide through professions. Within a number of enumerated professions and occupations, sports coaches are classified into the group Services - Personal Services - Sports and registered in the field 1014. Detailed descriptors of this profession are not prescribed. On the other hand, occupations in education, higher education and in the field of science Physical education and sports are classified into professions related to education and science. In the umbrella document, which regulates professions and occupations in Serbia, there is an outstanding question of the Sport profession, as well as the profession of sports coach, connecting the factor of accredited study programs (all three academic levels), courses for training and permanent improvement with the needs of sports users and labour market. This means that competencies acquired on the basis of knowledge and skills from many academic and professional areas governed by sports coaches are not recognized. In spite of such a gap in the documents that form a business career, higher education institutions in Serbia are issued work permits and are accredited study programs through which the vocational training is organized by a sports coach (Chart 2). Although the National Qualifications Framework did not take into account this, it should be known that the Law on Sports and the sub-legal act regulate professions in sports. However, for profession and occupation in sports it is neither an adequate nor a sufficient solution, because it allows too much arbitrariness in regulation and application. 

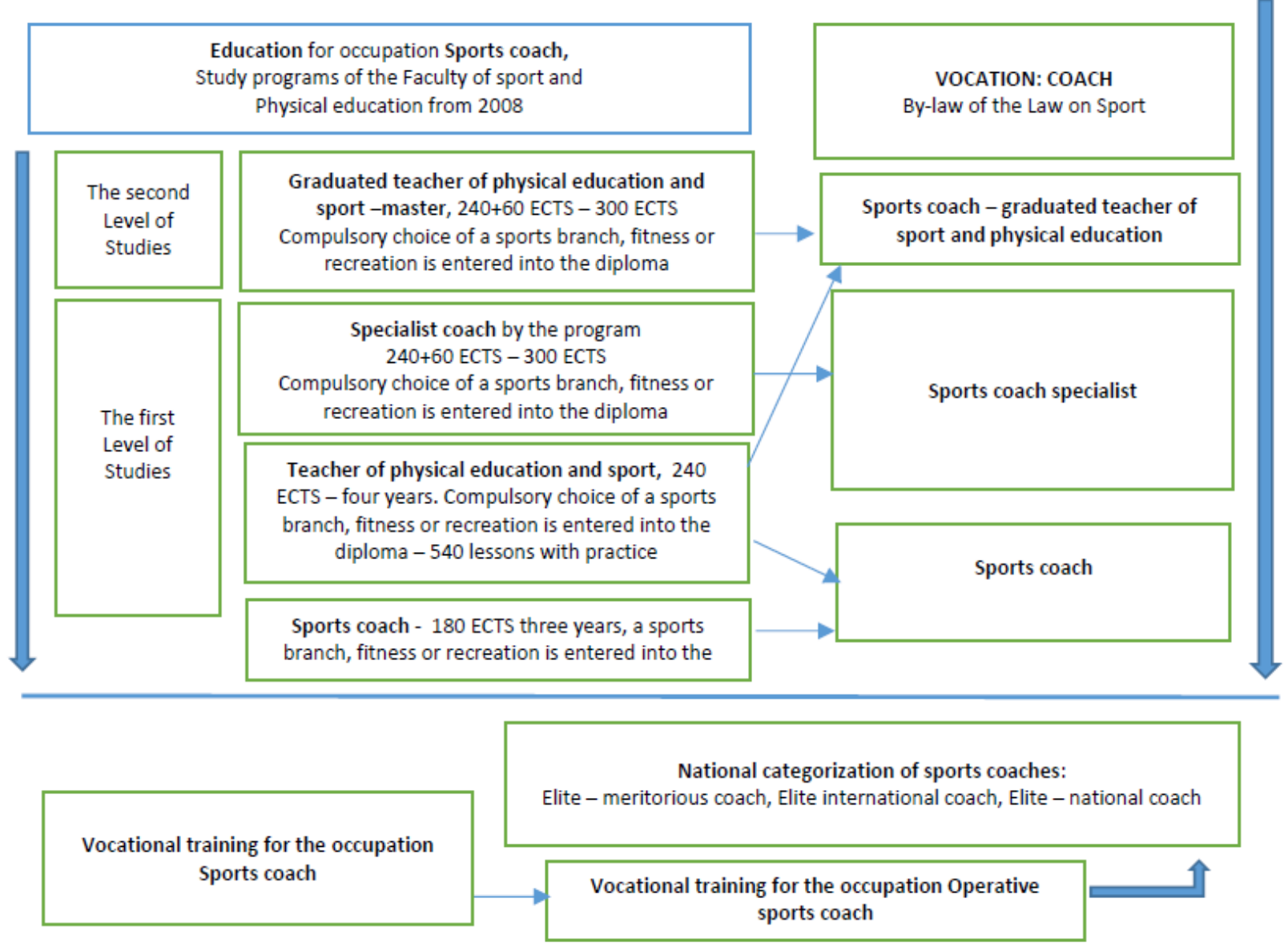

Chart 2. Model of education and professional training of sports coaches in Serbia

Based on a more detailed analysis of Chart 2 and comparison of study programs and solutions in the bylaws of the Law on Sports, a greater number of discrepancies are found for documents regulating higher education, according to which it is possible to propose reconsideration of certain solutions and their correction in the new by-laws of the MOS.

The Law on Sports and Documents stipulating occupations in sport (Nomenclature of occupations in sport) and the analysis of accredited programs of education and training programs indicate that the process of education and training of sports coaches takes place exclusively in favour of the competitive side of a particular sport. In the education and training programs of the trainer, the participant's side of the sport, which belongs to the mass sport (school sport, children's sports, sports at the university, sports for special groups, Para sport, sports for the elderly ...), is neglected. Certain rare attitudes in the Sports Law and Sport Nomenclature, as well as analysed study programs, only partially cover these areas with their curriculum. However, for them, in the docu- ments and practice, special titles and professions are not specified.

Based on the analysis of the documents on the work of sports experts, it was established that the work permit (license) is issued to coaches who have met the nine criteria, among which the first refers to completed education or training (acquired diploma - education or certificate of competence). In the Nomenclature of Sports in Sports, Article 9 states that they are characteristic, and we would also say very complicated tasks (outcomes of education or training) of coaches in sports: planning of training process, conducting training, control of preparedness and selection of athletes, analysis and correction of training processes and competitions, conducting performance in competitions; keeping records of work and results achieved, preparing work reports; providing material and technical conditions for exercising and training. However, in practice, there are at least two major problems: the first one, in which the sports coach is in the profession, equals all levels of education and training, and the second, who, on arrival to the ti- 
tle of sports coach, ignore the importance and role of non-formal and informal education. In other words, a sports coach in Serbia is awarded only through formal education, which does not pay attention to the basic descriptors that determine the competence of the trainer.

\section{INNOVATIVE STEPS FORWARD IN PROGRAMS OF TRAINING OF SPORTS COACHES AT THE FACULTY OF SPORT AND PHYSICAL EDUCATION IN BELGRADE, FROM 2001 TO 2006}

It took almost 65 years to go to the Faculty of Sport and Physical Education of the University of Belgrade, besides physical education (teaching), to open an academic study program for training of experts for sport (coaching) (Table 4). The establishment of this study program resulted in a step forward in improving the organization of the Faculty (the directions and sections were introduced), a more fundamental determi- nation of the scientific field and narrower scientific fields, the formation of new teaching subjects, the choice and employment of new teachers and associates... The epilogue is there were also organizations of a large number of chairs, and that, predominantly those from the field of sports. The faculty and individual teachers and associates were more closely connected with national sports and actively participated in determining the directions of the development of Serbian sports in the first years of its state independence (since 2006). The mission of the academic study program Sport, adopted in 2003, was clear: Provide higher education outcomes for sports professions with implications for sports, teaching and science practice, that is, profession and new occupations of importance to the society and the sports system of Serbia. As Serbia is affirmed as a country successful in sport, these efforts have been accepted by the University and founders (states), have been evaluated as a step towards excellence in education and professional innovation. On the inner, university level, these changes were accepted by a larger number of the teachers as a measure for "awakening dormant institutions and professions". The new study program was an incentive for the development of the sports system and its environment.

Table 4. Innovative period of the basic studies curricula (2001 - 2006) at the Faculty of Sport and Physical Education in Belgrade

\begin{tabular}{|c|c|c|c|c|}
\hline Periods & \multicolumn{4}{|c|}{ Basic structure of plans } \\
\hline From 1948 to $1999 / 2000$ & \multicolumn{4}{|c|}{$\begin{array}{l}\text { Four-year studies of physical culture, there are no sections or directions. Occupation: teacher of } \\
\text { physical education (programs were changed, but not outcomes and structure. Occasional directions to } \\
\text { sports are recorded) }\end{array}$} \\
\hline \multirow[b]{2}{*}{$2001 / 02$} & I and II year & \multicolumn{3}{|c|}{ III and IV year } \\
\hline & \multirow[t]{2}{*}{$\begin{array}{l}\text { Core } \\
\text { curriculum } \\
\text { courses }\end{array}$} & $\begin{array}{l}\text { Department: Sport Direction: Coaching: } \\
\text { Sport coach (sports branch or recreation) }\end{array}$ & $\begin{array}{l}\text { Department: Physical } \\
\text { education } \\
\text { Course: Teaching } \\
\begin{array}{c}\text { occupation: PE } \\
\text { teacher }\end{array}\end{array}$ & $\begin{array}{l}\text { Course: Recreation } \\
\text { Occupation: } \\
\text { Recreator } \\
\text { only } 2002 / 2003\end{array}$ \\
\hline $2003 / 04$ & & $\begin{array}{l}\text { Course: Coach } \\
\text { Core curriculum courses and chosen sports } \\
\text { branch, fitness or recreation }\end{array}$ & \multicolumn{2}{|c|}{ Course: Teacher } \\
\hline $2005 / 06$ & \multicolumn{4}{|c|}{$\begin{array}{l}\text { Department: Sport - Course: Coaching: } \\
\text { (Core curriculum courses and chosen sport, fitness or recreation, } 300 \text { ECTS) } \\
\text { Course: Teacher: PE teacher (240 ECTS): }\end{array}$} \\
\hline $\begin{array}{l}\text { Accreditations } 2008 / 09 \\
2014 / 15 \\
\text { and nowadays }\end{array}$ & \multicolumn{4}{|c|}{$\begin{array}{l}\text { BAS Physical education and sport, } 240 \text { ECTS } \\
\text { (No departments, courses, classes, departments for certain sports are cancelled) } \\
\text { Outcome: Teacher of physical education and sport (the chosen sports branch, fitness or recreation } \\
\text { studied at the III and IV year is entered into the diploma). Graduated student has fullfiled conditions to } \\
\text { gain licence for work in sport. He/she has not fulfilled conditions for work in education! Master studies } \\
\text { are necessary (60 ECTS) }\end{array}$} \\
\hline
\end{tabular}


At the time of its creation, this was a unique program context and powerful tool for the development of the Faculty as well as the development of sports through new knowledge and professional skills. It was an example of a well-timed curriculum, and probably motivation to other related faculties, both inside and outside Serbia, to go the same way and create similar and comparable study programs. The overpassing oneself was the need and attitude of the majority of the members of the collective from which it was necessary to create the activity of the Faculty within the three fields of the mission of the university (teaching, development of society, science) (Jevtić, 2017). Unfortunately, although it has managed to strengthen the reputation of the Faculty in the Serbian society and the sports system, intensify international cooperation, promote new occupations in education (sports coaches, sports managers) and add significant value to the higher education market of Serbia, this study program lasted only a few years, more precisely to the first accreditation according to the principles of Bologna (2008). With the accreditation documents from 2008, the Faculty of Sport and Physical Education of the University of Belgrade returned to "safe waters", from the period of its establishment (1945). The return to the "old" meant the abolition of sections and directions, and setting as a priority the curriculum for the teacher-professor of physical education with the obligatory orientation of students for occupations in sports, recreation or fitness. The epilogue is a curriculum for basic academic studies with 55 subjects, 45 compulsory subjects and 10 elective subjects. New teaching subjects (from 2001 onwards) and the program contents of the former study program Sport were retained in an accredited curriculum. The pragmatic interests of individual teachers in the work on a large number of subjects and the increased teaching load prevailed and resulted in greater monetary gain. In order to allow certain subjects to be taught by teachers who do not have the necessary education and competences, there were changes in the narrower scientific fields, so instead of four, only one remained for "Difovci", which is equalled to the science field Physical education and sports, and which "can bear it all" (Table 5). This method of defining narrow scientific areas at the Faculty in Belgrade is not comparable to any example in Serbia and beyond.

Table 5. Narrow scientific fields at the Faculty of Sport and Physical Education in Belgrade

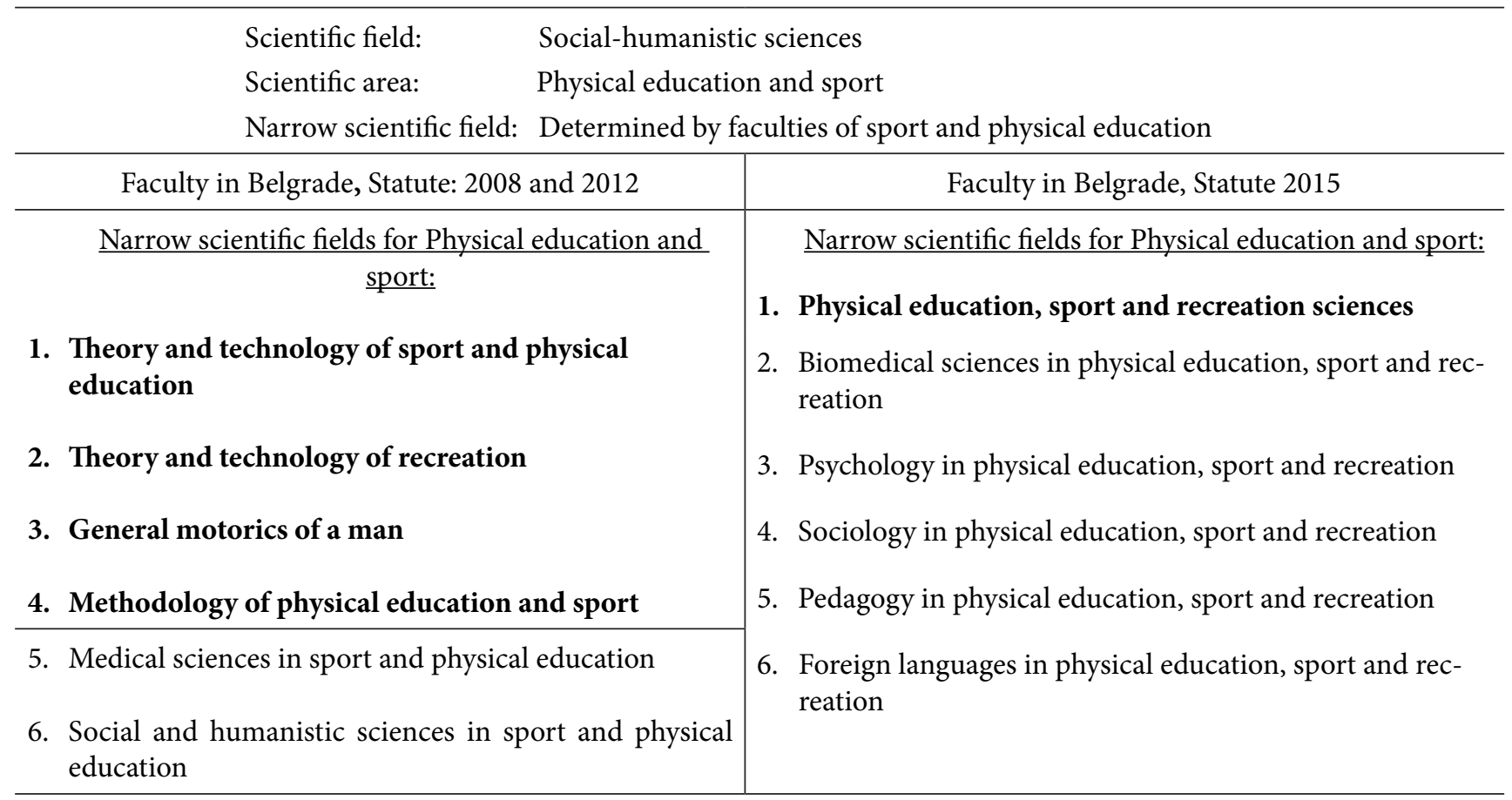


Why was it necessary in 2003 to have an academic study program "Sport"? The answer to this question should not be sought solely in the existence of identical study programs across the continent and the world, or, "in relation to domination and the most commonly used prefix sport for the designation of the faculty of moving culture of a man" (Bokan, 2017). The answer, first of all, should be sought in the needs of a modern man to show the ability of self-indulgence through the achievement of predetermined goals ... because sport itself is a "manifestation of freedom", and that is what derives from man's eccentric nature (Koprivica, 2018). It is no less important to point out that it is an intention of a modern society to enrich each member through spiritual and psycho-physical engagement and the idea of selfcomparison with the previous bio motor but also affective level. In other words, the personal and social result in sports is no longer material, but is above all a spiritual and symbolic product that can be regarded as free art - the eighth art within the art spectrum (McNamara et al, 2010). The fact that it arises freely, without external coercion, only with the "discourse" of its own spirit, and by being subjected to a certain design in advance, not only by rules, the sport is undoubtedly qualified as one original spiritual phenomenon (Koprivica, 2018). Therefore, sport has become an art for contemporary society, which includes the manifestation of free will, and the efforts of the practitioner to accept the challenges for their own changes and advancement. Achievement in sport, as well as in other creative activities, implies personal freedom, because sport is a civilization phenomenon that, by its expression, achieves links with culture, which goes beyond the traditional limits of its knowledge and understanding (Da Costa, 2010). These and similar sociological and philosophical determinants defined the creators of changes at the Faculty of these days to connect them, and to comprehend them fully and holistically, and to express sport in the new study program as an art that influences social processes and cultural phenomena, and which has positive effects on the bio-psycho-social-intellectual-motor-affective attributes of each of its members (Moragas, 2006). Encouraged by the need of a modern man, society and further academic development, from 2003 to 2008, teachers and associates of the Faculty accepted and participated in innovations and program step-up towards the fundamental values of sports (and physical education) in the $21^{\text {st }}$ century.

\section{STUDY PROGRAM PHYSICAL EDUCATION AND SPORTS FROM 2008 - A STEP FORWARD TOWARDS PROFESSION AND OCCUPATION IN SPORT OR A STEP BACK}

By the definition of John Scott (Scott, 2006), the main components of the mission of the university, according to their chronological order, are teaching, national influence, research, and international significance. The mission of the University of Belgrade is to provide the highest academic standards and acquiring knowledge and skills in accordance with the needs of society and projected national development through education, scientific research and participation in the development of the community. It is increasingly insisting on the third mission of the university, which is based on three pillars of development: technology transfer and innovation, continuous learning, socially responsible behaviour of the university. The third mission implies the relationship between the university and the community and opening of universities towards the outside environment. Faculties where physical education and sports are taught in Serbia realize their mission of university education through the field of Physical education and sports. The realization of the mission of the Faculty takes place through the dissemination of proven and new knowledge, technologies, innovations, with the aim of responding to the challenges of the third mission of the university.

Education and training of experts for sport and physical education in Serbia has been going on since 1938. Nevertheless, eight decades later, it seems that higher education continues to pursue the meaning of its role and place in the process of education for occupations in sports. It seems that the sports academic community is not aware of the fact that informal and non-formal sources in acquiring coaching knowledge and vocation are getting stronger. An example is the US sport system that relies on vocational training, lifelong learning and responsible employers as a priority in the development of the coach's structure. The success of the USA athletes is not questioned, but on the contrary, they are still a team with the highest number of medals when success is "measured" by the number of Olympic medals won in total according to the Olympic games. 
In Serbia, during the first decade of the $21^{\text {st }}$ century, the redefinition of the vision and mission of higher education and in the field of sports took place. In accordance with this, changes in the curricula were done, which were expected to lead to new occupations and competences in the field of sports (training, research, organization and management...). Unfortunately, these changes did not last long enough to be judged about their quality. More precisely, they lasted from 2001 until the first accreditation in accordance with the principles of the Bologna Process (2008).

The accreditation of numerous study programs at universities, including the field of physical education and sports since 2008, has established the evaluation of criteria for which the efficiency of studying is not perceived through professional competences, but above all, through the time for which the diploma is acquired. In other words, the output criteria, such as outcomes, competencies, willingness of graduates to work on different jobs ... or process criteria such as teaching, practice, business relationship ... although clearly defined by Accreditation Standards and Standards for self-evaluation of each of the Serbian faculties, however, have not yet become a benchmark for assessing the effectiveness of study programs for physical education and sports. Faculties in the field of physical education and sports are not ready to discuss institutional barriers and difficulties during higher education, as well as education for professions in sports and physical education. This is best seen from the inconsistencies of the curricula of basic academic studies at faculties in Serbia.

By analysing the organization and curricula of sports and physical education faculties at four state universities (Belgrade, Novi Sad, Niš, PrištinaLeposavić) and one private (Singidunum, Belgrade), it can be concluded that a state license and a job of a $\mathrm{PE}$ teacher is reached through the first and the second level of higher education and with the achieved 300 ECTS. Depending on the faculty of study, for the first 240 ECTS a student attends from 28 to 55 subjects. Since these are accredited study programs with faculty permits issued by the same national accreditation body, a space for a multitude of questions is opened, first of all, are the outcomes of accredited programs that lead to a license for work in education and sports precisely measured? If they are, why there is such a difference between the curricula and the number of engaged teachers and associates. Such large differences in study programs open the question of the adequacy of the process and the accuracy of the procedures leading to the accreditation of faculties and their work permits. It is not easy to give an answer to the question of the adequacy of the plan with 64 subjects within 300 ECTS at the Faculty of Sport and Physical Education of the University of Belgrade, when it is known that the diplomas from the period before the acceptance of the Bologna Process are equally valid, which were obtained in four years of studies and with 30-31 exams passed. Namely, if the jobs are well evaluated, the diplomas equally valid, then this means that the outcomes are identical. When comparing other criteria, and above all, how faculties are organized, the number of employed teachers and associates, the scientific fields studied (more than 100 scientific disciplines occur in the field of physical education and sports), the names of departments, the diversity in the plan of basic academic studies, professional studies, master academic and doctoral studies, and even the accreditation of doctoral studies that are not in the field of Physical education and sports as a science..., it can be concluded that there is no academic consensus on the educational process that leads to a degree in physical education and sports. Besides, although it has been developing in Serbia for more than 80 years, there is still a need to answer questions what the frameworks of the superimposed science "Physical Education and Sport", to which this conceptual definition of the culture and science of human physical activity should be its competence.

\section{CONCLUSION}

Sport "creates" many good things to individuals and the society that nourishes, respects, organizes, improves, celebrates it. The universality of the being of sport, recognized by the most important world organizations and individuals, is derived from the needs of a man and contemporary society. It should be an imperative for a different, much more serious approach and engagement of our sports and academic community.

An integral part of the affirmation of sport as a profession in Serbia is the Declaration of Magglingen (2000) which is unnoticed. Modern and affirmed occupations, primarily the profession of a sports coach, are covered by it. 
Sport is a profession of the $21^{\text {st }}$ century. As in most professions, as well as in sports, the profession consists of previous education, knowledge, career, career development, explicit ethical and value norms, occupational organization, professional practice, clarity in terms of roles and responsibilities.

Contrary to the general understanding that the profession of sport and occupation of a sports coach in Serbia are defined by all known categories, there are in reality many unresolved problems of status and profession and occupation.

The process of acquiring new knowledge and skills or the process of transforming the previous knowledge and experience into their new form and application (coaching skills) takes place through the interaction of formal, non-formal and informal knowledge and lifelong learning. These other two sources of knowledge are recognized with limitation in the programs of licensing coaches in Serbia.

The National Sports Federation, with the mediation of the international federation, is called upon to identify the needs and the process of education of a coach of the sports branch. Many of them, in their analyses, draw conclusions about the inefficiency of the coaches' professionals, which is why more and more coaches are being trained by mentors who transfer knowledge to the field and help young coaches in acquiring and forming professional skills.

Higher education in Serbia does not follow "signs along the way" of the leading sports, stock and political organizations, which strive to define the professional identity of a sports coach. There are a large number of references, scientific and professional journals dealing with this issue, which is rarely written in Serbia but is being spoken about on a daily basis.

The faculties of sports and physical education in Serbia, with their academic study programs, limited by the law or the rules of the university, as well as the factors of internal organization and development strategy, do not act responsibly towards the programs on education and training of the sport coaches they implement. Therefore, faculties of sport and physical education in Serbia need to reaffirm their mission, assess their business in relation to sports, but also to assess their place, role and importance in its development and the Serbian society. What the Faculty of Sport and Physical Education in Belgrade did in 2003 is forgotten, the idea is growing, the authority is spent. It is time for a new strategy and mission of higher education, a new beginning in relation to the profession and occupations in sports.
Based on the prominent features of sport in the $21^{\text {st }}$ century, it can be concluded that if Serbia wants to develop the profession Sport and its occupations, it is necessary to: redefine outcomes and the role of education for affirmations of interest and new occupations in sports; refresh the attitudes of the profession with the application of generally accepted, European and world trends in the development of sports. First of all, it is necessary to incorporate and respect international consensus and examples of good practice in national licensing criteria for coaches. At the same time, it is necessary to promote sports in accordance with the fact that it is a profession of the $21^{\text {st }}$ century.

In the part of education of sports personnel, what should be started is new study programs and their accreditation, before which the following conditions (Affirmation, Analysis, Application, Accreditation) should be fulfilled:

- Affirmation of the Third Mission of Universities aimed at the development of society, one of the first steps being the establishment of a Knowledge and Skills Transfer Office, with the aim of linking creators and knowledge users;

- An analysis of the situation and needs of the Serbian society, the agenda for its development, the market itself and the prospects of occupation, and as a way to increase the professional competence of the professionals for the new capacity of the labour market;

- Application of the methodology of "engaged research", but also the development of projects that can gain the confidence of international reviewers. Analysis of approved projects by international consortium indicates that they are realized through participatory sports. Research and innovation projects should be directed towards search for personal and social progress through sport, and

- Accreditation and external evaluation of study programs with outcomes in accordance with the principles of the $21^{\text {st }}$ century universities - really, not formally implemented.

- In accordance with the subject and purpose of this paper, academic study programs of sports should focus on the education of young professionals to sustain the personal and social values of sport through their profession, interests, innovations and new jobs. 


\section{REFERENCES}

1. Abraham, A., Collins, D. \& Martindale, R. (2006). The coaching shematic validation throug expert coach consensus. J of Sport Sci. 24:549-54.

2. Andonović, S. (2017). Pravo na sport kao ljudsko pravo. [The right to sport as a human right]. Strani Pravni Život, 3: 131-144.

3. Bokan, B. (2017). Časopis Fizička kultura - 70 godina trajanja. [The journal „Physical culture”: 70 years of duration]. Fizička kultura 71 (2): 154165

4. Chappelet, J.L. (2010). Autonomy of sport in Europe. Council of Europe Publishing, Strasbourg.

5. DaCosta, P.L. (2010). Olympic Studies - Current Intellectual Crossroads. Programa de Pós Graduação em Educação Física. Rio de Janeiro

6. Dick, F. (2011). The coaches pathway. Presentation to the Pathways in coaching excellence international workshop, Köln,

7. Duffu, P., Hartley, H., Bales, J., Crespo, M., Dick, F., Vardhan, D., Normann, L. \& Curado, j. (2011). Sport coaching as a "profession" : Challenges and future directions. International Journal of Coaching Science, 5(2):93-124.

8. Durantez, C.C., Perez-Turpin, A., Martinez Vidal, A., Pandoro M.C., Maryinez Patino, J. \& Molina, G.A. (2010). Principles of the Olympic Movement. J. of Human Sport and Exercise, on line, 5 (1):3-14, ISSN 1988-5202, doi 10.4100/jhse

9. Erickson, K., Bruner, W.M.;MacDonald, J.D. \& Côté, J.(2008). Gaining Insight into Actual and Preferred

10. Gobert, W. Cote, J., Mallet, C. (2006). Developmental paths and activities of successful sport coaches. Int. J. of Sport Sci and Coaching, 1: 69-76.

11. Guide to EU Sport Policy (2011). Brussels: EOC EU Office.

12. International Sport Choaching Framework / version 1.2 (2013). Illinois: Human Kinetics.

13. Jevtić, B. (2018). Olimpizam i studentski sport. [Olympism and student sport. In serbian]. U E. Kastratovic (ed): U duhu Olimpizma (str . 15-47). Beograd: Fakultet za biznis i pravo.

14. Jevtić, B. (2010). Sistem sporta, sportski stručnjaci i bolonjski proces. [Sports system, sports experts and Bologna process. In Serbian]. In G. Kasum i sar. Angažovanost nastno-naučnog kadra sa akreditovanih državnih fakulteta sporta u okviru aktivnosti nacionalnih sportskih saveza $i$ eltinih klubova u stručnog kadra iz nacionalnog sporta u sistemu obrazovanja i usavršavanja na akreditovanim sportkim državnim obrazovnim instirucijama. str.7-31. Beograd: Fakultet sporta i fizičkog vaspitanja i Ministarstvo omladine i sporta.

15. Jevtić, B. (2011a). Sistem sporta i dečiji sport. [A system of sports and children's sports. In Serbian] U B. Jevtić, J. Radojevič, I. Juhas, R. Ropret (Ed). Dečiji sport od prakse do akademske oblsti (str 6991). Beograd: Fakultet sporta i fizičkog vaspitanja.

16. Jevtić, B. (2014). Sport and enterpreneurship. In Proceedings "Techology, Culture and Development", pp 122-134, Belgrade. Asosciation Technlogy and Society.

17. Jevtić, B. (2017). Naučni časopis "Fizička kultura" u misiji razvoja naučne i društvene zajednice. [Scientific journal „Physical Culture” in the mission of scientific and social community development]. Fizička kultura 71(2), 182-194.

18. Koprivica, Č. (2018). Homo Maximus. Elementi filosofije sporta. [Homo Maximus. Elements of philosophy of sport. In Serbian]. Beograd, Ukronija.

19. Lemyre,F., Trudel, P. \&Durand-Bush, N. (2007). How Youth-Sport Coaches Learn to Coach. The Sport Psychologist, 2007, 21, 191-209

20. Lyle, J. (2007). A review of the research evidence for the Impact of Coaching Education. International J. of Coaching Science, 1(1):19-36.

21. Malcom, D., Piementa, N., Pihheiro, C.M. (2014). Could and Should Coaching become Profession? Some Sociological Reflectiions. Int. J. of Sports SciఓCoaching, 1(1): 42-45. doi: 10.1123/sci.20130017.

22. McNamara, A., Button, A., Collins, D. (2010). The role of psychological characteristics in facilitating the pathway to elite performance. The Sport Psychologist 24: 52-73.

23. Moragas, M. (2006). Academic institutuins and Olympic movement. V Forum on Sport Education and Culture Forum by IOC undertaken. Beijing. 
24. Parry, J. (2009). The etical and political values of the Olympic Movement. Etical and Political values of the Olympic Movement, Ghent

25. Petry, K., Froberg, K., Madella, A., Tokarski, W. (2008). Higer Education in Sport in Europe. Mayer\&Mayer (UK).

26. Radojević. J., Jevtić, B. (2011). Društvo i sport dece $\mathrm{i}$ omladine. [Society and sport of children and youth. In Serbian]. U B. Jevtić, J. Radojevič, I. Juhas, R. Ropret (Ed). Dečiji sport od prakse do akademske oblsti (str 31-44). Beograd: Fakultet sporta i fizičkog vaspitanja.

27. Scott, C.J. (2006 ). The mission of the University: Medieval to postmodern transformations. J. of Higher Education 77:1-39.

28. Sheridan, P.M. (2014). "Could and Should Sport Coaching Become a Profession? Some Sociological Reflections" A Commentary. International Sport Coaching Journal, 1: 46-49.

29. Smith, C.T.A.,Westerbeek, M.H. (2007). Sport as a vechile for deploying corporate social responsibility. The J. of Corporate Citizenship 25: 5-12.

30. Stoszkowski, J. \& Collins, D. (2015). Sources, topics and use of knowledge by coaches. Journal of Sport Science, 34(9):794-802.

31. Vocational education and training in the field of sport in the European Union: situation, trends and outlook. Vocaport (2004). Lion: EOSA.

32. Šuput, D. (2015). Nastajanje sportskog prava Evropske unije. [The emergence of EU sport law.]. Strani Pravni Život, 2:99-115.

\section{Documents}

1. Baza kvalifikacija u Republici Srbiji. [Qualifications base in the Republic of Serbia]. Dostupno na: http://noks.mps.gov.rs

2. Council of Europe (1992). European Sports Charter

3. European Commission (2007) White Paper on Sport

4. European Commission (2011) Developing the European dimension in sport

5. European Council (2000) Declaration on the Specific Characteristics of Sport and Its SocialFunction in Europe

6. European framework of qualification, www. cedefop.europe.eu

7. International Council for Coach Education. (2000). Magglingen Declaration

8. Nomenklatura zanimanja u sportu. [Nomenclature of occupation in sport. In Serbian]Ministarstvo omladine i sporta. Dostupno na: www. mos.gov.rs

9. United Nations (2000). Controbution of Sport to the Millennium development goals (www.un.org/ sport/sites/www.un.org.sport/files/documents/ $\mathrm{pdfs} /$ )

10. Zakon o nacionalom okviru kvalifikacijaRepublike Srbije (2018). [Law on National Qualifications Framework of Republic Serbia. In Serbian]. Dostupno na: www.mpn.gov.rs

11. Zakon o sportu Republike Srbije (2016). [Law on Sports of the Republic of Serbia. In Serbian]. Ministarstvo omladine i sporta. Dostupno na: www.mos.gov.rs 


\title{
АКАДЕМСКИ СТУДИЈСКИ ПРОГРАМИ И ШКОЛОВАЊЕ ЗА ПРОФЕСИЈУ СПОРТ, ЗАНИМАҢЕ СПОРТСКИ ТРЕНЕР
}

\author{
Јарослава Радојевић, Миљан Грбовић, Бранислав Јевтић \\ Факултет спорта и физичког васпитања, Универзитет у Београду, Србија
}

\begin{abstract}
Сажетак
Овај рад је сачињен на основу три сазнајна корака индуктивног и дедуктивног начина закључивања са циљем да се потврди положај спорта као значајног чиниоца друштвене стварности у овом веку, да се уоче проблеми у простору професије и занимања у спорту и да се предложе мере и активности којима би се (ус)поставила логичка стратешка линија за одређивање критеријума приликом формулисања професије и детерминација занимања у спорту. У првом сазнајном кораку издвајају се виђења мисије спорта за коју је оцењено да има непосредан и прворазредан значај за употпуњавање онтолошког и телесолошког учења о спорту у овом веку. У другом кораку сагледани су разлози који, како на националном, тако и на интернационалном нивоу, доводе до тога да се професија Спорт и занимања у спорту не препознају на адекватан начин. Уочени проблеми у простору академских студијских програма факултета у Србији су анализирани и доведени у везу са трендовима у образовању (школовање и оспособљавање) за занимање спортски тренер. У трећем кораку предложени су елементи за стратегију афирмације професије Спорт. Сврху рада треба разумети као корак у даљој цивилизацијској потврди значаја и улоге спорта, као и у обезбеђивању оквира за стратешко деловања у корист професије, постојећих и нових занимања у спорту. Подједнако важно је било препознати и, у овом раду, истаћи баријере у академским програмима српских факултета које треба превазићи ако се жели афирмација и прогрес Науке физичког васпитања и спорта.
\end{abstract}

КљУчне речи: СПОРТ / ПРОФЕСИЈА / ЗАНИМАЬА / СПОРТСКИ ТРЕНЕР / ТРЕЋА МИСИЈА УНИВЕРЗИТЕТА / СТУДИЈСКИ ПРОГРАМИ / СРБИЈА

\section{СПОРТ У КОРАК СА БИТЕМ И ПОТРЕБАМА САВРЕМЕНОГ ДРУШТВА}

Приступ којим се афирмишу вредности спорта у функцији развоја појединца и друштва у 21. веку, следе водеће међународне спортске организације, као и светске и континенталне спортске организације. Сличан, ако не и истоветан приступ месту и улози спорта у 21. веку се препознаје у документима и резолуцијама политичких организација (континенталних и интерконтиненталних). Тако, декларација и препоруке Уједињених нација из Манглингена „За бољи свет кроз спорт“ (2003) афирмише вредности спорта значајне за физичко и ментално здравље појединца, здраво одрастање ученика кроз спорт и физичко васпитање, изградњу квалитетних односа у друштву, прогрес локалне заједнице, превазилажење многобројних социјалних и културних баријера. Овај документ садржи поруке о спорту ослобођеног од допинга, испуњеног фер оносима према сваком и свим члановима спорта и самог друштва..., као и много тога другог. Канцеларија за спорт Уједињених нација, од 2008. године промовише спорт као средство за развој мира у складу са усвојеним Миленијумским циљевима. Унутар ове канцеларије делују сектори који су задужени за тематска подручја: Спорт и здравље, Спорт и полна - родна равноправност, Спорт и развој деце и омладине, Спорт особа са инвалидитетом, Спорт и мир. 
Водећа спортска организација у свету, Међународни олимпијски комитет (МОК) наводи документе и активности у складу са својом мисијом и агендом развоја спортског покрета (www. ioc.com). Анализа ових докумената доводи до закључака о потреби сталног надилажења улоге и мисије МОК-а, која се одвија и кроз динамику надградње ставова о савременом спорту, односно кроз програме којима се траже одговори на:

1. изазове МОКа $u$ целокупног спортског покрета о месту и улози спорта у културном (цивлизацијском) развоју, промоцији спорта у друштву, као и у очувању његовог легата;

2. питања значајних за утицај спорта у креирању „активног друштва“, учешће жена, деце и старих у спорту...;

3. тенденције у ширењу капацитета спорта у образовању младих и стицању пословних вештина за 21. век, као и у значају спорта на развој локалне заједнице;

4. недоумице у вези са спортском и професионалном каријером спортиста.

У Повељи Савета Европе дефинисано је да је спорт свака форма физичке активности која кроз, организовано или самостално учешће, има за циљ исказивање и побољшање физичке кондиције и менталног здравља појединца, гради и негује социјалне односе, и чини да се постижу резултати на такмичењима свих нивоа. Са тим у вези, учешће што већег броја грађана оба пола, свих узраста, радног и здравственог статуса, постизање личних, националних и врхунских резултатата, може се одредити као циљ спорта сваке чланице Савета Европе (CE).

Издавањем Беле књиге, која је допуњена „Лисабонским договором“ (2009), Европска унија настоји да свој и развој својих чланица афирмише кроз спорт. Ова два документа наглашавају специфичности спорта као "conditio sine qua non" у модерном друштву. Специфичности спорта се дефинишу и остварују кроз два нивоа: први, којим се поштује специфичност спортске активности и спортских правила (загарантована неизвесност такмичења, конкуренције и категорије...) и други, који садржи кораке којима се обезбеђују поштовање и неговање специфичности структуре и аутономија спорта, његова пирамидална организованост и афирмише се солидарност у спорту... (Chappelet, 2010).
Спорт је озбиљно третиран и у Белој књизи о међукултурном дијалогу ЕУ (2008), унутар које су препознати и високо вредновани његови образовни и васпитни ефекти и њихов значај за међукултурни дијалог и свеобухватне интеграције (Guide to EU sport policy, 2011).

У промоцији вредности спорта Европска унија финансира пројекте који имају значај за даљи развој и афирмацију вредности спорта, као што су инклузија, социјални дијалог, волонтеризам, каријера након спорта, животно окружење.... Своје политичке и економске циљеве укупног европског развоја реализује и кроз програме „Млади у акцији“, „Целоживотно учење“, „Европа за грађане“, „Здравствени програми“. Поред ових, истраживачким тимовима из спорта су приступачни фондови за науку и истраживања, као и фондови који финансирају развој европских региона. Спорту је отворен и програм „DAPHNE“ који је намењен спречавању дискриминације и злостављања деце, младих и жена.

Спорт у функцији развоја појединца, колектива и друштва, као и његов економски капацитет (спорт као индустрија) били су подстицај за правно уређење његових тековина и делатности. Временом, региструје се јачање регулаторне функције ЕУ у областима повезаним са спровођењем спортских активности и делатности, стварала се основа за постепени настанак и профилисање спортског права ЕУ (Шупут, 2015). У складу са модерним тенденцијама и проучавање спорта постао је својеврсни социјални феномен. Будући да је спорт јако важан чинилац друштвених односа, поставља се и питање да ли право на спорт представља људско право (Андоновић, 2017). Ипак, целовит поглед на питање човека и његовог спортског бића могућ је само кроз целовиту, теоријски, методолошки и гносеолошки засновану философију спорта, која се као дисциплина философије развија од шездесетих година прошлог века, да би у овом, 21. веку, остварила примат над истраживањима „позитивне науке“ (већи део спортских наука) која опстаје на поновљеним изучавањима већ утврђених чињеница експерименталних и лабораторијских посматрања померања телесности човека кроз спорт. Позитивистичком приступу, који искључује изучавање културног (цивлизацијског) контекста спорта, супроставља се философија спорта чије „крајеве“ сазнајног 
и методолошког континума детерминишу антропологија и феноменологија спорта (Схема 1, слика в). „Неодвојивост ових крајева може се изразити у виду јединственог питања "Како човек генерише спорт?" (Копривица, 2018). Односно у складу са предметом изучавања овог рада, потребно је одговорити на питање и осветлити како то бављење спортом генерише човека.

Дефинисање и третман спорта у његовој укупности, на начин како то промовишу најзначајније светске организације и појединци, нарочито његов утицај на биће и потребе савременог појединца и друштва, даје основу и подстиче на много озбиљнији приступ овом проблему и ангажовању у мањим, па и у нашој академској и спортској заједници.

\section{ОКВИРИ ИНТЕРПРЕТАЦИЈЕ МИСИЈЕ САВРЕМЕНОГ СПОРТА}

Спорт је специфична, аутономна и организована активност и делатност којом се остварују културне вредности, демократизује друштво, подиже квалитет живота, подстиче национални идентитет, културна различитост... Овим наводима није исцрпљено навођење свих вредности спорта које прерастају у утилитаризам као етичку теорију која тврди да је најбоља акција она која максимизира корист. До утилитаристичког приступа у разумевању спорта дошло се на основу анализе његове аксиолошке стране, која се у првим корацима свог стварања ослањала на романтичарске вредности спорта (понос, част, припадност, само-надмашивање, фер плеј, морална изузетност), да би се данас допунила и са просветитељским вредностима спорта (индивидуализам, универзализам, образованост, такмичарски контекст) (Parry, 2009). У следећем кораку, аксиолошка страна, односно дефинисање вредности спорта употпуњено је великим бројем теоријских и емпиријских чињеница о ефектима деловања спортом на појединца и друштво. Појединца на спорт подстиче његов дух који телу намеће спортску активност која се одвија у складу са правилима, али и кроз кооперативност, солидарност, постигнуће. Све то доводи до самонадилажења које је у функцији самоопредмећивања... „као мој резултат, моја другост која је произишла из мене“ (Копривица, 2018). Учешћем у спорту и новим искуством, човек мења свој карактер. Кроз одлучност, иницијативу, самоодређеност, иновацију, толерисање стреса, понекада и уз висок степен ризика по личну сигурност и здравље, решавају се многобројни проблеми духовног, психомоторичког, социјалног, фиктивног, афективног, материјалог, финансијског... карактера. Када је у питању друштво, спорт је постао средство и место на коме се вишестрано и вешеслојно ради на проблему одрживог развоја, као равнотеже између чинилаца животне и социо-економске средине, а у функцији цивилизације и будућности планете и њених становника. „Одрживост је резултат ефеката спорта на здравље, окружење, друштво... а само 30 минута дневне физичке активности обезбеђује значајан здравствени и економски бенефит. Савремени спорт, као и укупна физичка активност човека су испуњени циљевима, они подстичу на економску и еколошку одрживост, односно њиме се афирмишу односи по којима нам је економија потребна данас, а екологија и данас и сутра (Јевтић, 2010).

Спорт је значајна економска категорија унутар које се остварује скоро $3 \%$ укупног светског прихода, креирају се нова радна места и инвестира капитал. О спорту се данас говори и кроз дефиницију његових десет основних карактеристика у маркетиншком смислу (куповина, прихватљивости, промоција и медији, дистрибуција, производ, цена, објекти, такмичење, размена и запослени).

Смит и Вестербек (Smith, Westerback, 2007) су утврдили „јаку комуникациону моћ“ физичке активности путем које је могуће доћи до сваког члана заједнице, што за ефекат има да се физичка активност наводи као прво средство у „апелу младима“ за њихово одрастање у породици, спорту, образовању, култури, заједници (вежбачи, учесници, „фанови“). „Позитивни здравствени утицај“ је идеална платформа за свест о користи физичке активности за здравље сваког члана заједнице, као и подстицај за конкретну активност. Следе чиниоци физичке активности којима се, између осталог подстичу: „интеракција заједнице“ како у функционалном смислу, тако и у његовој демократизацији; тежња ка миру, социјалној кохезији, радости...; „свесност о одрживости“ и нултој толеранцији за нарушавање 
животне средине; „културна идентификација и интеграција“ и „непосредна добробит од задовољства“ која као таква инспирише чланове заједнице да вежбају, подржавају и високо вреднују физичку активност.

Може се закључити да нови миленијум афирмише спорт и спортски покрет као културну (цивилизацијску) тековину и вредност која доноси многа добра појединцу и друштву које га негује, организује, усавршава, слави.... (Јевтић, Радојевић, 2011). Спорт је постао организована активност којом се афирмишу личне, спортске, друштвене и етничке вредности. Њиме се демократизује друштво, подиже квалитет живота, јача здравље, подстиче национални идентитет. Спорт је активност којом се решавају питања друштвене искључености, младалачке деликвенције, фрагментације заједнице, њиме се друштва „боре“ са ефектима нарушеног здравља, скраћења радног и животног века човека (Радојевић, Јевтић, 2011). Данас, као можда више него икада пре, постоји потреба јачања вредности друштва, као што су труд, поштовање, солидарност, поверење, коегзистенција, социјална кохезија, етничка, полна и верска толеранција..., спорт је постао моћно средство ка том циљу, ка „оздрављењу друштва“ (Јевтић, 2018), јер је спорт на најдиректнији начин комфоран духу модерног времена, који се између осталог, огледа у императиву непрестаног подизања могућности у свим секторима друштвене стварности“ (Копривица, 2018).

Током 21. века спорт ће се, у значајнијој мери, интензивно и вишестрано изучавати, нарочито у простору друштвено хуманистичких наука. У том смилу, образовање кадрова за спорт добија, како нову функцију, тако и димензију која је различита од оних из прошлог века (Sheridan, 2014). јер спорт делује, како на морал тако и на физичку страну спортисте, односно, уз тренинг се развија и карактер и воља, једном речју, кроз спорт се ствара човек“ (Durantez, Perez-Turpin, Vidal, Pandoro, Patino, Molina, 2010). У складу са предметом, циљем и досадашњим разматрањима у овом раду, могло би се закључити да академске студијске програме спорта треба усмерити ка образовању младих стручњака да кроз своју професију, занимања, иновације и нове послове одрживо афирмишу личне и друштвене вредности спорта.

\section{СПОРТ - ПРОФЕСИЈА 21. ВЕКА}

Много пре акредитација високошколских установа и њиховог функционисања по принципима Деклерације из Болоње, још од 1938. године, у Србији се одвија образовање кадрова за занимања у образовању и спорту. У почетку то су били годишњи курсеви за наставнике и тренере, са циљем да се оспособе кадрови за рад у простору физичког вежбања најширег круга грађана. Ови курсеви су обавили своју функцију када је декретом Владе Федеративне Народне Републике Југославије (1945) започета изградња прве високошколске установе у Београду, која је од Државног института фискултуре (1947) прерасла у Факултет који је 1963. године примљен у чланство Универзитета у Београду.

У дугом временском периоду, од 1945. до 2000. године, у високошколском образовању у Србији су функционисали државни факултети са циљем школовања кадрова за занимања наставник физичког васпитања са повременим усмеравањима за рад у одређеним спортовима или рекреацији. Тако школовани кадрови били су прихваћени и цењени и у спорту. Наравно, време које је за нама имало је различит однос и приступ потребама друштва и његов развој кроз спорт од овог данашњег. Тако су и кадрови, који су се школовали за образовање, и без високе специјализације у тренажној и такмичарској методици и технологији, били носиоци већине стручних послова унутар система спорта. Ти кадрови су били носиоци дечијег и школског спорта, стратегије развоја младих спортиста и њиховог усавршавања до врхунског и елитног резултата. У тадашњем систему спорта није било поделе на приватни и комерцијални спорт, није било данашње професионализације, комерцијализације и глобализације спорта. Спорт је био национално добро!

У периоду од 2000. године, спорадично се отварало питање професије и занимања у спорту. Најчешће поводом усвајања докумената којима се ближе одређују занимања у спорту. (Ради ближег одређења, ова документа се у Републици Србије доносе на нивоу државног органа задуженог за спорт). Међутим, при томе су остале непримећене, или боље рећи занемарене потребе препознавање струке, корисника, услова рада, модернизација и 
савременост појединих спортова..., као и значајне међународне иницијативе које за циљ имају квалитет спортске услуге, самим тиме и кадрова и програма у спорту. Тако је остала непримећена и Декларација из Манглингена (2000) која садржи десет препорука за рад спортског тренера. Прва од тих препорука односи се на етичко понашање и механизам за мониторинг етичког приступа у раду тренера. Следе: систематизација компетентности тренера; образовање и оспособљавање у складу са потребама спортисте и спорта; место и улога тренера у развоју спортисте свих нивоа. Значајан део се односи на целоживотно учење, на образовање тренера у односу на слободан приступ и динамику школовања у складу са обавезама у тренерском раду. Саставни део декларације из Манглингена је и настојање да се дефинише професија Спорт и да се преко ње кровно покрију савремена и афирмисана занимања, пре свих, занимање спортски тренер. Социолози сматрају да је овај део декларације проблематичан и да ће се отежано решавати, јер свака професија би требало да садржи мериторан, ауторитаран и одлучујући глас о питањима струке, а то када је у питању спорт није тако (Malcom, Pimenta, Pinherio, 2013).

\section{Проблем професије и занимања у спорту}

обележје спорта у 21. веку, како у Европи, тако и у САД, као и већини других региона света је, поред осталог и повећан број послова који доводе до увећања броја занимања којима се ствара „производ“ који афирмише економске и друштвене вредности спорта. Поред традиционалних занимања, као што су спортски тренери, инструктори спортских активности, менаџери, лекари, физиотерапеути, новинари, менаџери спортских објеката..., у спорту се отварају и нова радна места и креира нова друштвена стварност и економска вредност (табеле 1 и 2).

Табела 1 Могући послови и радна места у савременом спорту (Јевтић, 2014)

\begin{tabular}{|c|c|c|c|c|}
\hline $\begin{array}{c}\text { Производња } \\
\text { спортских добара }\end{array}$ & $\begin{array}{c}\text { Менаџери } \\
\text { пројеката, програма }\end{array}$ & Публикације & Кладионице & $\begin{array}{c}\text { Спортски догађаји, } \\
\text { заједница }\end{array}$ \\
\hline $\begin{array}{c}\text { Производња и } \\
\text { продаја опреме, } \\
\text { обуће }\end{array}$ & $\begin{array}{c}\text { Консултанти, } \\
\text { истраживачи, } \\
\text { јавна и национална } \\
\text { политика, лобисти... }\end{array}$ & $\begin{array}{c}\text { Обучавање } \\
\text { (choaching) } \\
\text { појединца и тима }\end{array}$ & $\begin{array}{c}\text { Пројектовање и } \\
\text { експлоатација } \\
\text { спортских објеката }\end{array}$ & $\begin{array}{c}\text { Догађаји у масовном } \\
\text { спорту }\end{array}$ \\
\hline $\begin{array}{c}\text { Спортски маркетинг, } \\
\text { менаџмент и } \\
\text { промоција }\end{array}$ & $\begin{array}{c}\text { Менаџмент } \\
\text { спортског догађаја }\end{array}$ & $\begin{array}{c}\text { Опрема за фитнес и } \\
\text { теретане }\end{array}$ & $\begin{array}{c}\text { Спортска } \\
\text { фотографија- филм }\end{array}$ & $\begin{array}{c}\text { Психолошка } \\
\text { припрема и } \\
\text { психијатрија }\end{array}$ \\
\hline Спортска медицина & $\begin{array}{c}\text { Менаџмент } \\
\text { волонтера у спорту }\end{array}$ & $\begin{array}{c}\text { Веб дизајн и } \\
\text { друштвене мреже }\end{array}$ & $\begin{array}{c}\text { Спортска исхрана и } \\
\text { суплементи }\end{array}$ & Рачуноводство \\
\hline $\begin{array}{c}\text { Старење и физичка } \\
\text { активност }\end{array}$ & Екстремни спорт & Сервис опрема & $\begin{array}{l}\text { Информације и } \\
\text { спортске вести }\end{array}$ & Ревизија \\
\hline Здравље и фитнес & Спортски туризам & Блогови & $\begin{array}{c}\text { Производња трофеја } \\
\text { и меморабилија }\end{array}$ & Дизајн \\
\hline $\begin{array}{c}\text { Безбедност и } \\
\text { сигурност }\end{array}$ & $\begin{array}{c}\text { Учеснички-масовни } \\
\text { спорт }\end{array}$ & $\begin{array}{c}\text { Продаја справа и } \\
\text { реквизита }\end{array}$ & Спорт и забава & $\begin{array}{c}\text { Осигурање и } \\
\text { каријера спортиста }\end{array}$ \\
\hline Комерцијални спорт & $\begin{array}{c}\text { Професионални } \\
\text { спорт }\end{array}$ & $\begin{array}{c}\text { Симулатори и } \\
\text { софтверска решења }\end{array}$ & $\begin{array}{c}\text { Информациони } \\
\text { системи }\end{array}$ & Пројекти за ЕУ \\
\hline $\begin{array}{c}\text { Рекреација } \\
\text { физичким } \\
\text { активностима }\end{array}$ & $\begin{array}{c}\text { Спортска } \\
\text { организација }\end{array}$ & $\begin{array}{c}\text { Изградња и } \\
\text { одржавање } \\
\text { спортских површина }\end{array}$ & $\begin{array}{c}\text { TВ; интернет, радио } \\
\text { канали }\end{array}$ & Е - продаја \\
\hline
\end{tabular}


Европска комисија за класификацију економских активности (NACE) прати економску активност у области спорта, анализирајући два сектора: спортски сектор или активности које су повезане са вежбањем, и спортску индустрију која подржава спортске активности, као њихов нераздвојиви део.

Табела 2 Могући послови и послодавци у спорту у Србији (Јевтић, 2014)

\begin{tabular}{|c|c|c|c|c|}
\hline Јавне установе & $\begin{array}{c}\text { Основне и средње } \\
\text { школе }\end{array}$ & $\begin{array}{c}\text { Спортски клубови - } \\
\text { франшизе }\end{array}$ & $\begin{array}{l}\text { Јавни и приватни } \\
\text { спотрски центри }\end{array}$ & Аматерски клубови \\
\hline Влада & $\begin{array}{c}\text { Факултети и } \\
\text { универзитети }\end{array}$ & Спортске федерације & Власти Покрајина & $\begin{array}{c}\text { Шира спортска } \\
\text { заједница }\end{array}$ \\
\hline Школе & $\begin{array}{c}\text { Заводи за спорт, } \\
\text { истраживачка } \\
\text { одељења }\end{array}$ & $\begin{array}{l}\text { Међународне } \\
\text { спортске } \\
\text { организације }\end{array}$ & $\begin{array}{c}\text { Националне и } \\
\text { међународне } \\
\text { корпорације }\end{array}$ & Медији \\
\hline $\begin{array}{c}\text { Аматерски и } \\
\text { професионални } \\
\text { тренери }\end{array}$ & $\begin{array}{c}\text { Комерцијални } \\
\text { делови спортских } \\
\text { федерација - Лиге }\end{array}$ & $\mathrm{HBO}$ & $\begin{array}{c}\text { Афирмисани } \\
\text { спортисти }\end{array}$ & $\begin{array}{c}\text { Професионални } \\
\text { спорт }\end{array}$ \\
\hline Грађани & $\begin{array}{c}\text { Територијалне } \\
\text { (спортске и друге) } \\
\text { организације }\end{array}$ & $\begin{array}{c}\text { Национални } \\
\text { олимпијски комитет }\end{array}$ & ИТ & Туризам \\
\hline Војска & Полиција & Верске заједнице & Социјална политика & Здравствени систем \\
\hline $\begin{array}{l}\text { Јединице локалне } \\
\text { самоуправе }\end{array}$ & $\begin{array}{c}\text { WEB и друштвени } \\
\text { медији }\end{array}$ & Цивилна заштита & $\begin{array}{c}\text { Пројектовање и } \\
\text { изградња }\end{array}$ & $\begin{array}{c}\text { Приватна } \\
\text { иницијатива }\end{array}$ \\
\hline
\end{tabular}

Према подацима Петруа и сарадника (Petry, K., Froberg, K., Madella, A., Tokarski, W., 2008), дакле пре десет година, скоро 1\% запослених у Великој Британији ради у спорту и областима везаним за спорт, што чини 10,8 запослених на 1000 вежбача. Овај однос се разликује унутар ЕУ, па тако у Аустрији 6 запослених долази на 1000 вежбача, у Холандији 5,5, Шпанији 4,8, а у Немачкој 4 запослена на 1000 вежбача. Процењује се да је у САД скоро 300.000 запослених у спорту са пуним радним временом, и милион запослених у спорту са непуним радним временом. Другим речима, ново доба афирмише велики број занимања у спорту. Спорт 21. века оријентисан је ка културним (цивилизацијским) вредностима у одрживом развоју појединца, друштва и природе. Сходно томе, региструје се и велики број иницијатива којима се чува културно биће спорта и делује у правцу његове економске одрживости кроз предузетничке иницијативе, иновације и самозапослење (Јевтић, 2014).

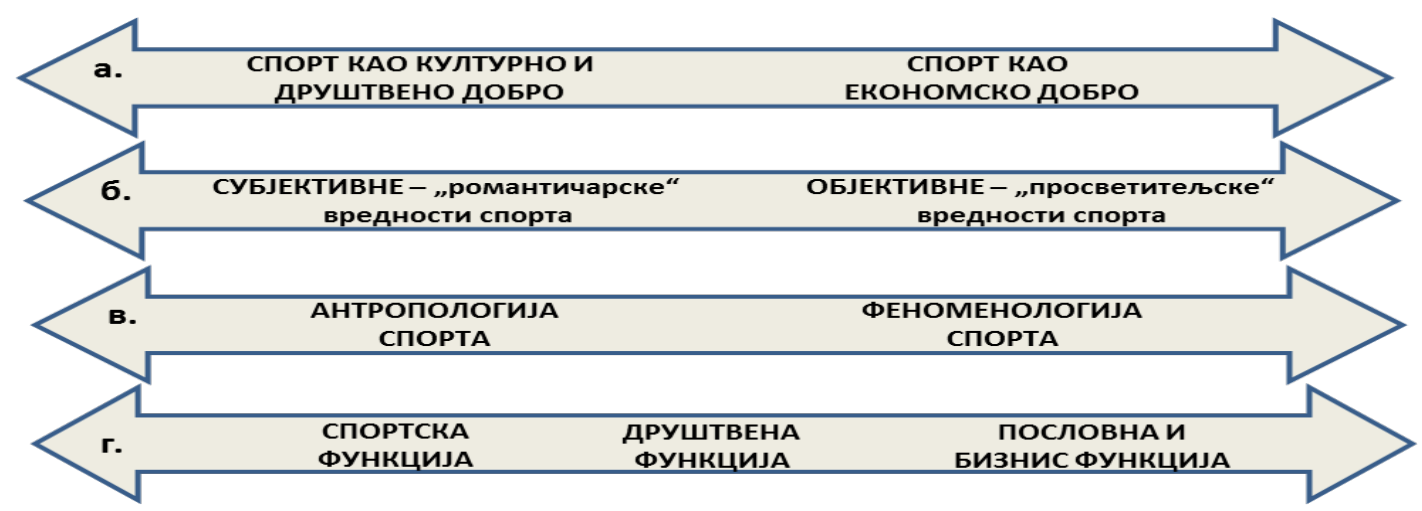

Схема 1 Онтолошки (а), аксиолошки (б), сазнајни (в) и пословни (г) континуум спорта (Јевтић 2014, 2018) 


\section{Школовање и оспособљавање за занимање спортски тренер}

Тренер је једно од најстаријих занимања које своје порекло води из периода античких цивилизација. Развој савременог друштва довео је до тога да занимање спортски тренер постане предмет многобојних дебата и расправа које су довеле до напуштања становништа да се ради само о послу учења моторичких вештина (Gobert, Cote, Mallet, 2006). Данас се спортски тренери школују и оспособљавају кроз дефинисане програме за стицање стручне квалификације који су испуњени знањима, вештинама и рутином у корист спортисте-вежбача (спортоцентричност система). Другим речима, у спорту се уочавају напори управљања квалитетом на свим нивоима спортског организовања. Поставком и реализациом своје мисије кроз моделе управљања квалитетом, спорт се определио за темељну редефиницију своје мисије и, могло би се рећи да се усмерио ка изградњи своје професије. Супротно општем схватању да су професија спорт и занимање спортски тренер дефинисане и свима познате категорије, у стварности постоје бројни нерешени проблеми статуса и професије и занимања (Duffu, Hartley, Bales, Crespo et al, 2011).

Спортски тренери раде на основу великог броја пословних и високо стручних знања, вештина и способности, као што су она о поставци програма и решавању недоумица тренажног процеса, планирање, посматрање, праћење реализације плана, анализа ефеката, закључивања, доношења судова... о програму и спортисти у тренажном процесу. Спортског тренера описују његове когнитивне, практичне, афективне и пословне вештине. Тренер приоритетно планира и реализује програме који ће довести до побољшања тренираних перформанси у односу на неки од, узрасних, полних, здравствених, моторичких, социјалних, васпитних атрибута појединца-групетима.

Занимање спортски тренер обликовало се око пет главних улога тренера: (1) улога у тренингу; (2) специјализована улога према групама спортиста (деца, инвалиди, таленти...); (3) васпитна улога; (4) руководећа улога (као селектор или шеф стручног штаба), и (5) компактна и комплексна улога око управљања изградњом врхунског спортског резултата (Dick, 2011). Овим наводима треба додати и улоге којима се тренер у 21. века усмерава ка иновацијама у тренажом процесу и афирмише кроз предузетничку активност како у економском тако и у социјалном миљеу.

Занимању и лиценци за обављање послова спортског тренера претходи учење на основу екстензивне листе извора знања из формалних, неформалних и информалних извора. Занимање спортски тренер је постало јединствено и по томе, што се у њему сусрећу и балансирају формално и неформално образовање. Искорак овог занимања је и информално учење које доминира и које тренера чини више професионалцем, самосталним и успешним како у тренажном послу, тако и на тржишту радне снаге. Ефикасност у занимању спортски тренер одређена је диспозицијом појединца за целоживотно учење о чему сликовито говоре и подаци из табеле 3. 
Табела 3 Врсте образовања и извори знања за занимање спортски тренер (припремљено према: Abraham, Collins,Martindale, 2006; Lemyre,Trudel,Durand-Bush, 2007; Erickson, Bruner, MacDonald, Côté, 2008; Stoszkowski, Collins, 2015)

\begin{tabular}{|c|c|c|c|c|}
\hline \multicolumn{2}{|c|}{ Формално образовање } & \multicolumn{3}{|c|}{ Неформално и информално образовање } \\
\hline предавања & курсеви & рефлексија & $\begin{array}{c}\text { посматрања и анализа } \\
\text { такмичења }\end{array}$ & стручна путовања \\
\hline вежбе & наставници & конференције & $\begin{array}{c}\text { посматрања рада других } \\
\text { тренера }\end{array}$ & инострани тренери \\
\hline $\begin{array}{l}\text { практична } \\
\text { настава }\end{array}$ & $\begin{array}{c}\text { формални и } \\
\text { неформални } \\
\text { ментори }\end{array}$ & конгреси & $\begin{array}{c}\text { посматрања врхунских } \\
\text { спортиста }\end{array}$ & тренерска периодика \\
\hline $\begin{array}{l}\text { семинари (као } \\
\text { форма наставе) }\end{array}$ & други студенти & семинари & видео анализе & приручници \\
\hline $\begin{array}{c}\text { књиге и } \\
\text { периодика }\end{array}$ & $\begin{array}{l}\text { информациони } \\
\text { системи }\end{array}$ & курсеви & блогови & ментори, старији тренери, \\
\hline $\begin{array}{c}\text { комплементарне } \\
\text { науке и области }\end{array}$ & $\begin{array}{c}\text { технологија } \\
\text { других спортова }\end{array}$ & клинике & $\begin{array}{c}\text { интернет презентације и } \\
\text { модели учења }\end{array}$ & тренинг један на један \\
\hline $\begin{array}{c}\text { физичко } \\
\text { васпитање, } \\
\text { прилагођено }\end{array}$ & $\begin{array}{l}\text { писање пројеката, } \\
\text { завршних радова }\end{array}$ & $\begin{array}{c}\text { вођења својих } \\
\text { спортиста - } \\
\text { тимова, спаринг } \\
\text { партн. }\end{array}$ & $\begin{array}{l}\text { информационе } \\
\text { платформе }\end{array}$ & индустрије спорта \\
\hline $\begin{array}{l}\text { вежбање, спорт у } \\
\text { институцијама... }\end{array}$ & $\begin{array}{l}\text { управљање и } \\
\text { руковођење у } \\
\text { спорту }\end{array}$ & други спортови & $\begin{array}{c}\text { планирање и } \\
\text { реализација тренинга } \\
\text { појединца и тима }\end{array}$ & $\begin{array}{c}\text { друге области } \\
\text { комплементарних спорту, } \\
\text { тренингу и резултату }\end{array}$ \\
\hline $\begin{array}{c}\text { тематске } \\
\text { радионице }\end{array}$ & $\begin{array}{c}\text { образовна и } \\
\text { стратегија спорта }\end{array}$ & $\begin{array}{c}\text { родитељи } \\
\text { спортиста, } \\
\text { наставници }\end{array}$ & $\begin{array}{c}\text { сертификовани } \\
\text { тренажни програми } \\
\text { НСФ и МСФ }\end{array}$ & $\begin{array}{c}\text { научници, запослени } \\
\text { у спорту (селектори, } \\
\text { директори програма, } \\
\text { аналитичари, } \\
\text { физиотерапеути...) }\end{array}$ \\
\hline $\begin{array}{c}\text { програми } \\
\text { оспособљавања }\end{array}$ & $\begin{array}{c}\text { тутори и методе } \\
\text { пројекта и } \\
\text { проблемске } \\
\text { наставе }\end{array}$ & $\begin{array}{c}\text { искуства из } \\
\text { спорта - спортова }\end{array}$ & самотренирање & $\cdots$ \\
\hline \multicolumn{2}{|c|}{$L^{L}$} & \multicolumn{3}{|c|}{$\mathbf{T}$} \\
\hline \multicolumn{2}{|c|}{$\begin{array}{c}\text { Учење - теоријски и концептуални } \\
\text { оквир биомедицинских, друштвено- } \\
\text { хуманистичких и наука о спорту (не и о } \\
\text { професији и занимању спортски тренер) }\end{array}$} & \multicolumn{3}{|c|}{$\begin{array}{c}\text { Учење усмерено пословима спортског тренера } \\
\text { (знања и вештине адекватна занимању) }\end{array}$} \\
\hline
\end{tabular}

Стицање компетентности за тренерски посао требало би да се одвија кроз две фазе које се могу посматрати и одвојено, али се у суштини ради о интегралном процесу. У првој фази, развој и стицање прве тренерске лиценце заснива се на компетенцијама за реализовање програма у учесничком (масовном) спорту. Другом фазом доминарају програми који воде до изгадње компетентности за врхунски и елитни резултат.
Иако се ради о интегралном процесу, ипак, ове две фазе су само шаблонски идентичне (Vocaport, 2004). Без обзира на то да ли је реч о учесничком или врхунском спорту, занимање спортски тренер предодређено је за оне који су оријентисани целоживотном учењу, који истрајавају на прокламованој мисији спорта, који су инспирисани за увођење иновација у рад и окружење спортисте. Најзначајније информације 
које тренери стичу током образовања и каријере су из простора специфичних тренажних метода (са скоро 50\% значајности) са темама: како планирати и тренирати; моторно учење; комуникација и анализа перформанси. Стозовски и Колинс (Stoszowski, Collins, 2015) истичу да се код тренера временом смањују интересовања за теме из наука примењених у спорту (психологија, физиологија, биомеханика). Наводе и да рефлексија стеченог, претходног спортског и тренерског искуства, води до смањења интересовања за знања из технике и тактике и других знања која се односе спортску грану или дисиплину. Извори које тренери цене као релевантне за даље учење, по редоследу разврставају се од комуникације са другим тренерима, следе клинике, семинари, конференције, анализе видео материјала, гле= дање такмичења (непосредно и на ТВ), књиге, часописи, па све до прегледних и апликативних чланака у научним часописима. Пошто се ради о целоживотном учењу, очигледно је да у плану целовитог програма образовања (школовања и оспособљавања) спортског тренера, унајплоднијој фази њиховог развоја, доминирају информални извори знања са 93\% заступљености, јер: „свака особа стиче и усваја знања, вештине, формира ставове из дневног искуства и кроз комуникацију са окружењем, (извод из Европског оквира квалификације). Од науке тренери очекују да им да одговоре на питања из менталног тренинга, изградње тима, исхрани, физичкој припреми, кондицији, превенцији повреда и опоравку, али и одговоре који се односе на разумевања потреба данашњих спортиста (Stoszowski, Collins, 2015). Стога, посао спортског тренера треба посматрати као комплексну, динамичну активност и запослење које је засновано на контексту струке, али и тенденцијама које описују савременог професионалца. Оно је, као и остала савремена занимања, предодређено чиниоцима система спорта, друштва и технологије тренажног процеса (Lyle, 2006). Избор занимања спортски тренер зависи од фактора унутрашње и спољашње мотивације, као и владања диспозицијама за његово обављање. Знања и компетентност у струци се јављају као унутрашњи, а радно место и његови атрибути, као спољашњи фактор за одлуку о избору професије и занимања. То значи да решавање проблема своје професије и занимања, тренери и тренерске организације треба да започну од регулисања спољашњих фактора, који излазе из простора технологије и методике тренажног рада и блиско су одређени стратегијом укупног друштвеног развоја. Спољашњим факторима припадају и студијски програми за школовање за занимање спортски тренер.

\section{Професија спорт, школовање и оспособљавање за звање спортски тренер у Србији}

Током 2018. године у Србији је први пут усвојен Национални оквир квалификација, документ значајан за сваку професију и водич кроз занимања. Унутар великог броја пописаних професија и занимања, спортски тренери су разврстани у групу Услуге - Личне услуге Спортови и заведени у поље 1014. Детаљни дескриптори овог занимања нису прописани. $\mathrm{Ca}$ друге стране, занимања у образовању, високом образовању и у области науке Физичко васпитање и спорт су сврстана у професије повезане са образовањем и науком. У кровном документу, који регулише професије и занимања у Србији, остало је недоречено питање професије Спорт, као и занимања спортски тренер, које је повезујући чинилац акредитованих студијских програма (сва три академска нивоа), курсева за оспособљавање и перманентно усавршавање са потребама корисника спорта и тржишта рада. То значи да нису препознате компетенције стечене на основу знања и вештина из бројних академских и стручних области којима владају спортски тренери. И поред таквог јаза удокументима којима се обликује пословна каријера, институцијама високог образовања у Србији издају се дозволе за рад и акредитују се студијски програми кроз које се одвија образовање за занимање спортски тренер (Схема 2). Иако Национални оквир квалификација то није узео у обзир, треба знати да се Законом о спорту и подзаконским актом, регулишу занимања у спорту. Међутим, за професију и занимања у спорту то није ни одговарајуће ни довољно решење, јер омогућује сувише произвољности у регулисању и у примени. 

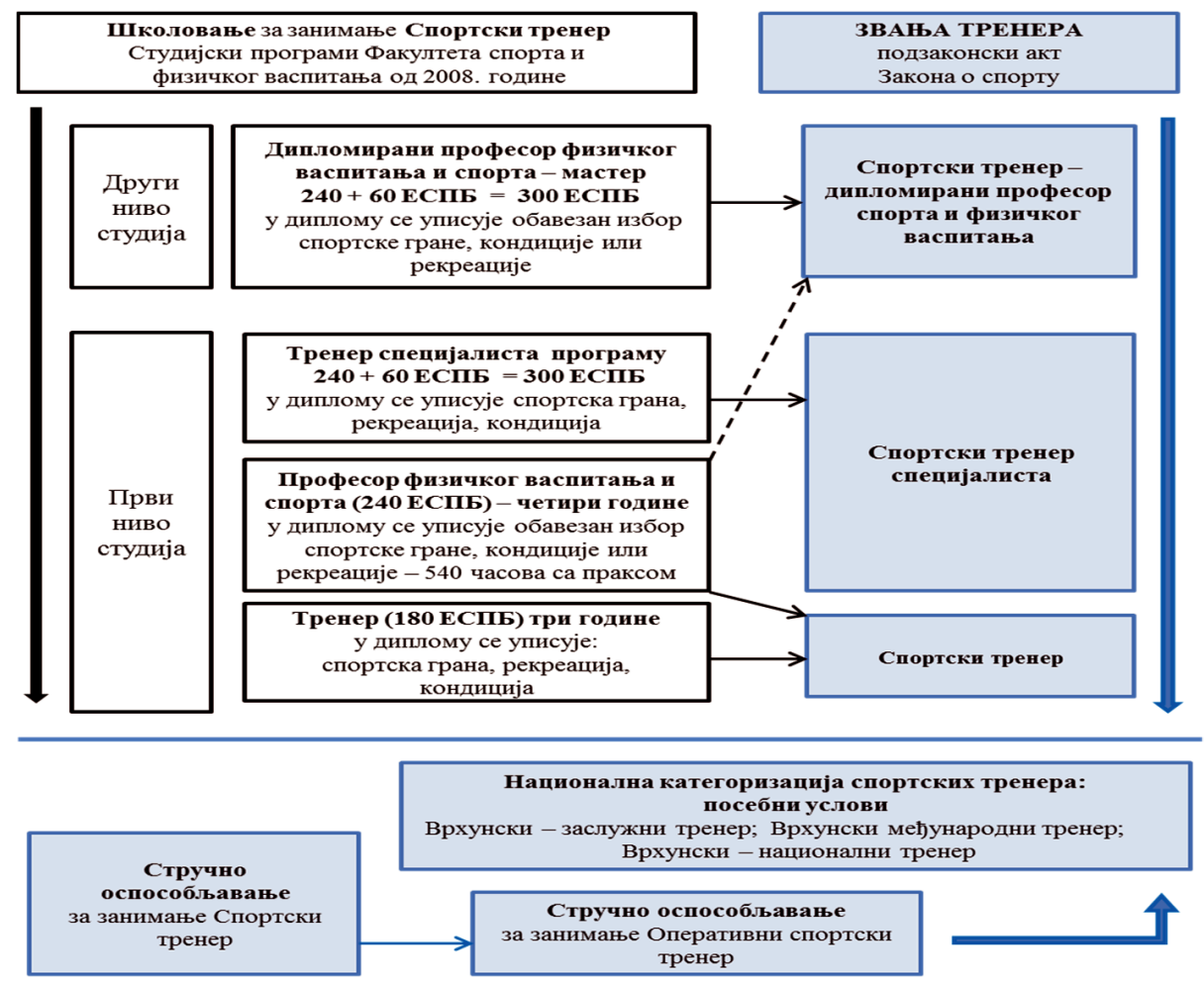

Схема 2 Модел школовања и стручног оспособљавања спортских тренера у Србији

На основу детаљније анализе схеме 2 и упоређивања студијских програма и решења у подзаконским актима Закона о спорту уочава се већи број неусаглашености за документима којима се регулише високо образовање, сходно чему се може предложити поновно разматрање одређених решења и њихово кориговање у новим подзаконским актима МОСа.

Закон о спорту и документи који прописују занимања у спорту (Номенклатура занимања у спорту) и анализа акредитованих програма школовања и програма оспособљавања, указују да се процес школовања и оспособљавања спортских тренера одвија, искључиво у корист такмичарске стране одређеног спорта. У програмима школовања и оспособљавања тренера занемарена је учесничка страна спорта, којој припада масовни спорт (школски спорт, дечији спорт, спорт на универзитету, спорт специјалних група, параспорт, спорт старијих....). Одређени, ретки, ставови у Закону о спорту и номенклатури занимања у спорту, као и анализирани студијски програми, само делимично, програмски покривају и ове области. Међутим, за њих, у документима и пракси, нису одређена посебна звања и занимања.

На основу анализе докумената о раду спортских стручњака установљено је да се дозвола за рад (лиценца) издаје тренерима који су испунили девет критеријума, међу којима се први односи на завршено школовање или оспособљавање (стечена диплома - образовање или уверење о оспособљености). У Номенклатури занимања у спорту, у члану 9 наведено је да су карактеристични, а ми бисмо рекли и веома сложени послови (исходи образовања или оспособљавања) тренера у спорту: планирање тренажног процеса, вођење тренинга, контрола припремљености и селекција спортиста, анализа и корекција тренажног процеса и такмичења, вођење наступа на такмичењима; вођење документације рада и постигнутих резултата, припремање извештаја о раду; обезбеђивање материјално техничких услова за извођење вежбања и тренажног процеса. Међутим, у пракси уочавају се најмање два велика проблема: први, којим су у занимању спортски тренер, изједначени сви нивои образовања и оспособљавања и, други, који у доласку до звања спортски тренер, занемарује значај и улогу неформалног и информалног образовања. Другим речима, до звања спортски тренер у Србији се стиже само кроз формално образовање, чиме се не поклања пажња основним дескрипторима којим са одређује компетентност тренера. 


\section{ИНОВАТИВНИ ИСКОРАЦИ У ПРОГРАМИМА ШКОЛОВАЊА СПОРТСКИХ ТРЕНЕРА НА ФАКУЛТЕТУ СПОРТА И ФИЗИЧКОГ ВАСПИТАҢА У БЕОГРАДУ ОД 2001. ДО 2006. Г.}

Било је потребно да прође скоро 65 година па да се на првооснованом, данашњем, Факултету спорта и физичког васпитања Универзитета у Београду, поред физичког васпитања (наставнички смер) отвори и академски студијски програм за школовање стручњака за спорт (тренерски смер) (Табела 4). Успостављање овог студијског програма имало је за резултат искораке у правцу усавршавања организације Факултета (уведени су смерови и одсеци), темељнију детерминацију научног поља и ужих научних области, формирање нових наставних предмета, избор и запослење нових наставника и сарадника.... Епилог је и била и организација већег броја катедара и то, доминантно оних из простора спорта. Факултет и поједини наставници и сарадници су се, у већој мери, повезали са националним спортом и активно учествовали у одређивању праваца развоја спорта Србије у првим годинама њене државне независности (од 2006. године). Мисија академског студијског програма Спорт, који је усвојен 2003. године, била је јасна: Обезбедити високошколске исходе за занимања у спорту са импликацијама на праксу спорта, наставу и науку, односно на професију и нова занимања од значаја за друштво и систем спорта Србије. Како је Србија афирмисана као спортски успешна земља, ова настојања су била прихваћена од стране Универзитета и оснивача (држава), вреднована су као искорак ка изузетности у школовању и стручним иновацијама. На унутрашњем, факултетском плану, ове промене су од већег дела наставничког колектива биле прихваћене као мера за „буђење успаване институције и струке“. Нови студијски програм је био подстицај за развој система спорта и његовог окружења.

Табела 4 Иновативни периоди планова основних студија (2001 - 2006) на Факултету спорта и физичког васпитања у Београду

\begin{tabular}{|c|c|c|c|c|}
\hline Периоди & \multicolumn{4}{|c|}{ Основна структура планова } \\
\hline од 1948. до 1999/2000. & \multicolumn{4}{|c|}{$\begin{array}{c}\text { Четворогодишње студије физичке културе, нема одсека ни смерова. Занимање: наставник } \\
\text { физичког васпитања (програми су се мењали, али не и исходи и структура. Региструју се } \\
\text { повремена усмеравања према спорту) }\end{array}$} \\
\hline \multirow[b]{2}{*}{$2001 / 02$} & $\begin{array}{c}\text { I и II } \\
\text { година }\end{array}$ & \multicolumn{3}{|c|}{ III и IV година } \\
\hline & \multirow[t]{2}{*}{$\begin{array}{c}\text { Заједничке } \\
\text { основе }\end{array}$} & $\begin{array}{c}\text { Одсек: Спорт } \\
\text { Смер: Тренерски занимање: } \\
\text { Спортски тренер (спортска грана или } \\
\text { рекреација) }\end{array}$ & $\begin{array}{l}\text { Одсек: Физичко } \\
\text { васпитање } \\
\text { Смер: Наставнички } \\
\text { занимање: } \\
\text { Наставник } \\
\text { физичког } \\
\text { васпитања }\end{array}$ & $\begin{array}{l}\text { Смер: Рекреација } \\
\text { Занимање: Рекреатор } \\
\text { само 2002/2003. }\end{array}$ \\
\hline $2003 / 04$ & & $\begin{array}{c}\text { Смер: Тренерски } \\
\text { заједнички предмети и изабрана } \\
\text { спортска грана, кондиција или } \\
\text { рекреација }\end{array}$ & \multicolumn{2}{|c|}{ Смер: Наставнички } \\
\hline $2005 / 06$ & \multicolumn{4}{|c|}{$\begin{array}{c}\text { Одсек Спорт - Смер: Тренерски: } \\
\text { (заједнички предмети и изабрани спорт, кондиција или рекреација, } 300 \text { ЕСПБ) } \\
\text { Смер: Наставнички: Наставник физичког васпитања (240 ЕСПБ): }\end{array}$} \\
\hline $\begin{array}{l}\text { Акредитације 2008/09, } \\
\begin{array}{l}2014 / 15 . \\
\text { и данас }\end{array}\end{array}$ & \multicolumn{4}{|c|}{$\begin{array}{c}\text { ОАС Физичко васпитање и спорт, } 240 \text { ЕСПБ } \\
\text { (нема одсека, смерова, одељења, гасе се катедре појединачних спортова) } \\
\text { Исход: професор физичког васпитања и спорта (у диплому се уписује изабрана спортска грана, } \\
\text { кондиција или рекреација која се изучава на III и IV години). Свршени студент има услове за } \\
\text { лиценцу за рад у спорту. Нема услове за лиценцу за рад у образовању! неопходан је Мастер } \\
\text { студијски програм (60 ЕСПБ) }\end{array}$} \\
\hline
\end{tabular}


У моменту настанка, ово је био јединствен програмски контекст и моћно средство плана како развоја Факултета тако и развоја спорта путем нових знања и професионалних вештине. Био је пример добро одмереног студијског плана и програма, а вероватно и мотивација другим сродним факултетима, у и ван Србије, да крену истим путем и креирају сличне и упоредиве студијске програме. Надилажење себе је била потреба и став већине чланова колектива из кога је било потребно креирати делатност Факултета унутар три поља мисије универзитета (настава, развој друштва, наука) (Јевтић, 2017). Нажалост, иако је успео да ојача углед Факултета у српском друштву и систему спорта, интензивира међународну сарадњу, промовише нова занимања у школовању (спортски тренери, спортски менаџери) и да значајно приходује на тржишту високог образовања Србије, овај студијски програм је трајао тек неколико година, тачније до прве акредитације по принципима Болоње (2008). Акредитационим документима из 2008. године Факултет спорта и физичког васпитања Универзитета у Београду се вратио у „сигурне воде“, из периода оснивања (1945). Повратак на „старо“ је подразумевао укидање одсека и смерова, и поставку плана и програма студија приоритетно око занимање наставник - професор физичког васпитања са обавезним усмеравањем студената за занимања у спорту, рекреацији или кондицији. Епилог је наставни план основних академских студија са 55 предмета, 45 обавезних и 10 изборних предмета. Нови наставни предмети (од 2001. године надаље) и програмски садржаји некадашњег студијског програма Спорт задржани су у акредитованом наставном плану. Превладали су прагматични интереси појединих наставника за рад на већем броју предмета и повећаном наставном оптерећењу које им доноси већу новчану корист. Како би се омогућило да одређене наставне предмете предају наставници, који за њих немају потребно образовање и компетенције, уследиле су промене и ужих научних области, тако да је уместо четири, за „Дифовце“ остала само једна, која је изједначена са научном области Физичко васпитање и спорт, и која „трпи све“ (Табела 5). Наведени начин дефинисања ужих научних области на Факултету у Београду није упоредив ни са једним примером у Србији и шире.

Табела 5 Уже научне области на Факултету спорта и физичког васпитања у Београду

\begin{tabular}{|c|c|}
\hline \multicolumn{2}{|c|}{$\begin{array}{c}\text { Научно поље: } \quad \text { Друштвено-хуманистичке науке } \\
\text { Научна област: } \\
\text { Физичко васпитање и спорт } \\
\text { Уже научне области: одређују факултети спорта и физичког васпитања }\end{array}$} \\
\hline $\begin{array}{l}\text { Факултет у Београду } \\
\text { Статут: 2008. и } 2012 .\end{array}$ & $\begin{array}{c}\text { Факултет у Београду: } \\
\text { Статут } 2015 .\end{array}$ \\
\hline \multirow{2}{*}{$\begin{array}{l}\text { 1. Теорија и технологија спорта и физичког } \\
\text { васпитања } \\
\text { 2. Теорија и технологија рекреације } \\
\text { 3. Општа моторика човека } \\
\text { 4. Методологија физичког васпитања и спорта }\end{array}$} & $\begin{array}{l}\text { Уже научне области за матичност физичко васпитање и } \\
\text { спорт: } \\
\text { 1. Науке физичког васпитања, спорта и рекреације }\end{array}$ \\
\hline & \multirow{2}{*}{ 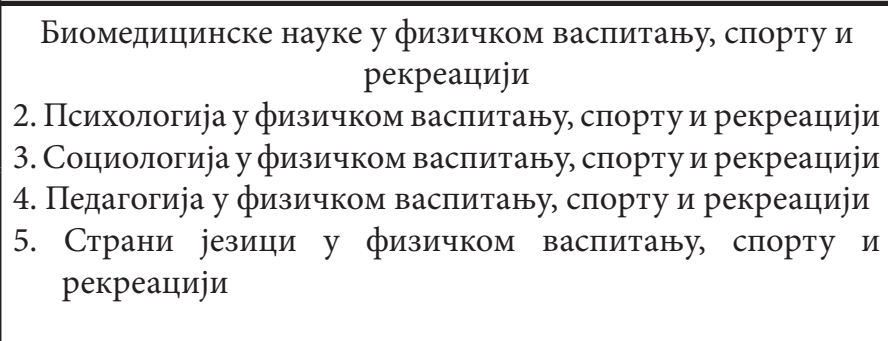 } \\
\hline $\begin{array}{l}\text { 5. Медицинске науке у спорту и физичком } \\
\text { васпитању } \\
\text { 6. Друштвено-хуманистичке науке у спорту и } \\
\text { физичком васпитању }\end{array}$ & \\
\hline
\end{tabular}


Због чега је те 2003. године био потребан академски студијски програм „Спорт“? Одговор на ово питање не треба тражити само у постојању истоветних студијских програма широм континента и света, или, „у односу на доминацију и најчешће коришћен префикс спорт за ознаку факултета за кретну културу човека" (Бокан, 2017). Одговор, пре свега, треба тражити у потребама савременог човека да покаже способност самонадилажења кроз постизање претходно постављених циљева... јер је спорт сам по себи „манифестација слободе“, а то је оно што проистиче из човекове екцентричне природе (Копривица, 2018). Није мање значајно истаћи да је интенција савременог друштва да се сваки његов члан оплемени кроз духовно и психофизичко ангажовање и идеју самопоређења са претходним биомоторичким али и афективним нивоом. Другим речима, лични и друштвени резултат у спорту није више материјални већ је, пре свега, духовни и симболички производ који се може посматрати као слободнауметност - осмауметност унутар спектра уметности (McNamara et al, 2010). Тиме што настаје слободно, без спољне принуде, једино уз „наговор“ властитог духа, и тиме што се унапред подвргава одређеном осмишљавању, не само путем правила, спорт се несумњиво квалификује као један изворно духовни феномен (Копривица, 2018). Дакле, спорт је за савремено друштво постаоуметност која садржи испољавање слободне воље, и настојање вежбача да прихвати изазове за властите промене и напредовање. Постигнуће у спорту, као и у другим креативним активностима, подразумева личну слободу, јер је спорт цивилизацијски феномен који својом експресијом остварује везе са културом чиме иде ван традиционалних граница свог сазнања и разумевања (Da Costa, 2010). Ове и њима сличне социолошке и философске одреднице определиле су тадашње креаторе промена на Факултету да изврше њихово повезивање, те да их целовитохолистички сагледају и да, у новом програму изучавања, спорт искажу као уметност која утиче на друштвене процесе и културне феномене, и која има позитивне ефекте на био-психосоцијалне-интелектуалне-моторичке-афективне атрибуте сваког његовог члана (Moragas, 2006). Подстакнути потребом савременог човека, друштва и даљег академског усавршавања, од 2003. до 2008. године наставници и сарадници
Факултета прихватају и учествују у иновацијама и програмским искорацима ка темељним вредностима спорта (и физичког васпитања) у 21. веку.

\section{СТУДИЈСКИ ПРОГРАМ ФИЗИЧКО ВАСПИТАҢЕ И СПОРТ ОД 2008. ГОДИНЕ - ИСКОРАК КА ПРОФЕСИЈИ И ЗАНИМАЫИМА У СПОРТУ ИЛИ КОРАК УНАЗАД}

По дефиницији Џон Скота (Scott, 2006), главне компоненте мисије универзитета, према њиховом хронолошком реду, су настава, национални утицај, истраживања и интернационални значај. Мисија Универзитета у Београду јесте да кроз образовање, научноистраживачки рад и учешће у развоју друштвене заједнице, омогући највише академске стандарде и обезбеди стицање знања и вештина у складу са потребама друштва и пројектованим националним развојем. Све се више инсистира на трећој мисији универзитета, која се занива на три стуба развоја: трансфер технологија и иновације, континуирано учење, друштвено одговорно понашање универзитета. Трећа мисија подразумева однос универзитета и заједнице и отварања универзитета према спољашњем окружењу. Факултети на којима се изучава физичко васпитање и спорт у Србији остварују мисију универзитетског образовања кроз научну област Физичко васпитање и спорт. Реализација мисије Факултета одвија се путем ширеть проверених и нових знаға, технологија, иновација, уз тежњу да се одговори на изазове треће мисије универзитета.

Школовање и оспособљавање стручњака за спорт и физичко васпитање у Србији одвија се од 1938. године. Ипак, осам деценија касније, као да високо образовање и даље трага за смислом своје улоге и места у процесу школовања за занимања у спорту. Спортска академска заједница као да није свесна чињеница да јачају информални и неформални извори у стицању тренерског знања и звања. Пример је систем спорта САД који се у развоју тренерске структуре ослања, приоритетно на стручно оспособљавање, целоживотно учење и одговорне послодавце. Успех спортиста САД овим није доведен у питање, чак напротив, оне су и даље делегација са највећим бројем медаља када се успех „премери“ бројем освојених олимпијских 
медаља укупно по играма олимпијаде.

У Србији се током прве деценије 21. века одвијала редефиниција визије и мисије високог образовања и у области спорта. У складу са тим извршене су и измене наставних планова и програма од којих се очекивало да доведу до нових занимања и компетентности у простору спорта (тренинг, истраживања, организација и менаџмент...). Нажалост, ове промене нису довољо дуго трајале да би се донео суд о њиховом квалитету. Тачније, трајале су од 2001. године до прве акредитације у складу са принципима болоњског процеса (2008).

Акредитацијом бројних студијских програма на универзитетима, па и у области физичког васпитања и спорта од 2008. године успостављено је вредновање критеријума којима се ефикасност студирања не сагледава кроз професионалне компетенције, већ, и пре свега, кроз време за које се стиже до дипломе. Другим речиима, излазни критеријуми, као што су исходи, компетенције, спремност дипломаца за рад на различитим пословима... или процесни критеријуми, као што су настава, пракса, веза са привредом... иако су јасно дефинисани Стандардима за акредитацију и Стандардима за самовредновање сваког од српских факултета, ипак, још увек нису постали мерило за оценуефикасности студијскихпрограма физичког васпитања и спорта. Факултети из простора физичког васпитања и спорта нису спремни да расправљају о институционалним баријерама и потешкоћама током високошколског образовања, па и школовања за занимања у спорту и физичком васпитању. То се најбоље види из неуједначености наставних планова основних академских студија на факултетима у Србији.

Анализом организације и наставних планова факултета спорта и физичког васпитања на четири државна универзитета (Београд, Нови Сад, Ниш, Приштина-Лепосавић) и једног приватног (Сингидунум, Београд) може се закључити да се до државне лиценце и радног места у настави физичког васпитања стиже кроз први и други ниво високог образовања и са остварених 300 ЕСПБ. У зависности од факултета на коме студира, студент за првих 240 ЕСПБ слуша од 28 до 55 предмета. Како се ради о акредитованим студијским програмима, и дозволама за рад факултета које је издало исто национално акредитационо тело, отвара се простор за многобројна питање, пре свега да ли су исходи акредитованиих програма који воде до лиценце за рад у образовању и спорту прецизно измерени? Ако јесу, чему толика разлика у наставним плановима и броју ангажованих наставника и сарадника. Овако велике разлике у студијским програмима отварају питање адекватности процеса и прецизности поступака који воде до акредитације факултета и њихових дозвола за рад. Није лако дати одговор на питање адекватности плана са 64 предмета у оквиру 300 ЕСПБ на Факултету спорта и физичког васпитања Универзитета у Београду, тим пре када се зна да подједнако важе дипломе из периода пре прихватања болоњског процеса, до којих се стизало за четири године студија и са 30-31 положеним испитом. Наиме, ако су радна места добро евалуирана, дипломе подједнако важеће, онда то значи и да су исходи истоветни. Када се упореде и друга мерила, а пре свега, како су факултети организовани, број запослених наставника и сарадника, које се уже научне области изучавају (више од 100 уже научних области се јавља у простору науке Физичко васпитање и спорт), називи катедара, различитост плана основних, струковних мастер и докторских студија, па чак и акредитација докторских студија који нису из простора науке Физичко васпитање и спорт..., може се закључити да не постоји академски консензус о процесу образовања којим се стиже до дипломе у простору физичког васпитања и спорта. Поред тога, иако се у Србији развија дуже од 80 година, и даље је актуелна потреба да се одговори на питања који су оквири октроисане науке „Физичко васпитање и спорт“ коме на стручност иде ово појмовно одређење за културу и науку човекове физичке активности.

\section{ЗАКЉУЧАК}

Спорт „ствара“ многа добра појединцу и душтву које га негује, поштује, организује, усавршава, слави. Свеукупност бића спорта, коју препознају најзначајније светске организације и појединци, изведена је из потреба човека и савременог друштва. Она би требало да буде императив за другачији, много озбиљнији приступ и ангажовање наше спортске и академске заједнице. 
Саставни део афирмације спорта, као професије је, код нас у Србији, непримећена Декларација из Манглингена (2000). Њоме се кровно покривају савремена и афирмисана занимања, пре свих занимање, спортски тренер.

Спорт је професија 21. века. Као и у већини професија, тако и у спорту, професију чине претходно образовање, знања, каријера, пут развоја кадрова, експлицитне етичке и вредносне норме, сталешка организација, професионална пракса, јасноћа у погледу улога и надлежности.

Супротно присутном општем схватању да су професија спорт и занимање спортски тренер у Србији дефинисане и свима познате категорије, у стварности постоје бројни нерешени проблеми статуса и професије и занимања.

Процес стицања нових знања и вештина или процес трансформације претходнх знања и искуства у њихов нови облик и примену (тренерска вештина) одвија се кроз интеракцију формалног, неформалног и информалног знања и целоживотног учења. Ова друга два извора знања су ограничено препознати у програмима лиценирања тренера у Србији.

Национална спортска федерација, уз посредовање међународне федерације позвана је да идентификује потребе и процес образовања тренера спортске гране. Многе од њих, у својим анализама долазе до закључака о неефикасности тренерског кадра, због чега све више ангажују тренере менторе који на терену преносе знања и помажу младим тренерима у стицању и формирању професионалних вештина.

Високо образовање у Србији не прати „знакове поред пута“" водећих спортских, сталешких и политичких организација, које теже дефинисању професионалног идентитета занимања спортски тренер. Велики је број референтних научних и стручних часописа који се баве овом проблематиком о којој се у Србији ретко пише али се свакодневно говори.

Факултети спорта и физичког васпитања у Србији, својим академским студијским програмима, ограничени законом или правилима универзитета, као и факторима унутрашње организације и стратегије развоја, не наступају одговорно према програмима о школовању и оспособљавању спортских тренера које реализују. Стога, факултети спорта и физичког васпитања у Србији треба да реафирмишу своју мисију, да процене своју пословност у односу на спорт, али и да процене своје место, улогу и значај у његовом и развоју српског друштва. Оно што је Факултет спорта и физичког васпитања у Београду учинио 2003. године је заборављено, идеја расточена, ауторитет потрошен. Време је за нову стратегију и мисију високог образовања, нови почетак у односу на професију и занимања у спорту.

На основу истакнутих обележја спорта у 21. веку, може се закључити да, ако се у Србији жели развој професије Спорт и занимања која јој припадају, потребно је: редефинисати исходе и улогу школовања за афирмисана занимања и нова занимања у спорту; освежити ставове струке уз примену општеприхваћених, европских и светских тенденција у развоју спорта. Пре свега, неопходно је у националне критеријуме за лиценцирање тренера уградити и поштовати међународне консензусе и примере добре праксе. Истовремено, потребно је промовисати спорт у складу са чињеницом да се ради о професији 21. века.

У делу школовања кадрова за спорт, оно од чега треба започети јесу нови студијски програми и њихова акредитација, пре којих треба испунити следеће услове (Афирмација, Анализа, Апликација, Акредитација), и то:

- афирмација Треће мисије универзитета усмерене ка развоју друштва, при чему би један од првих корака био формирање канцеларије за трансфер знања и вештина, са циљем повезивања стваралаца и корисника знања;

- анализа стаюа и потреба српског друштва, агенде његовог развоја, самог тржишта и перспективе занимања, а као начин да се увећа стручна компетенција кадрова за нови капацитет тржишта радне снаге;

- апликација методологије „ангажованих истраживања“, али и израда пројеката који могу задобити поверење међународних рецензената. Анализа одобрених пројеката међународних конзорцијума указује да се исти реализују кроз учеснички спорт. Истраживачки и иновациони пројекти треба да буду усмерени у правцу трагања за личним и друштвеним прогресом кроз спорт, и 
- акредитација и екстерна евалуачија студијских програма са исходима у складу са принципима универзитета 21. века стварно, а не формално спроведени.
У складу са предметом и циљем овог рада, академске студијске програме спорта треба усмерити ка образовању младих стручњака да кроз своју професију, занимања, иновације и нове послове, одрживо афирмишу личне и друштвене вредности спорта.

\section{ЛИТЕРАТУРА}

1. Abraham, A., Collins, D. \& Martindale, R. (2006). The coaching shematic validation throug expert coach consensus. J of Sport Sci. 24:549-54.

2. Andonović, S. (2017). Pravo na sport kao ljudsko pravo. Strani Pravni Život, 3: 131-144.

3. Бокан, Б (2017). Часопис Физичка култура - 70 година трајања. Физичка култура 71 (2): 154165

4. Chappelet, J.L. (2010). Autonomy of sport in Europe. Council of Europe Publishing, Strasbourg.

5. DaCosta, P.L. (2010). Olympic Studies - Current Intellectual Crossroads. Programa de Pós Graduação em Educação Física. Rio de Janeiro

6. Dick, F. (2011). The coaches pathway. Presentation to the Pathways in coaching excellence international workshop, Köln,

7. Duffu, P., Hartley, H., Bales, J., Crespo, M., Dick, F., Vardhan, D., Normann, L. \& Curado, j. (2011). Sport coaching as a "profession" : Challenges and future directions. International Journal of Coaching Science, 5(2):93-124.

8. Durantez, C.C., Perez-Turpin, A., Martinez Vidal, A., Pandoro M.C., Maryinez Patino, J., Molina, G.A. (2010). Principles of the Olympic Movement. J. of Human Sport and Exercise, on line, 5 (1):3-14, ISSN 1988-5202, doi 10.4100/jhse

9. Erickson, K., Bruner, W.M.;MacDonald, J.D. \& Côté, J.(2008). Gaining Insight into Actual and Preferred

10. Gobert, W. Cote, J., Mallet, C. (2006). Developmental paths and activities of successful sport coaches. Int. J. of Sport Sci and Coaching, 1: 69-76.

11. Guide to EU Sport Policy (2011). EOC EU Office, Brussels.

12. International Sport Choaching Framework / version 1.2 (2013). Human Kinetics, Illinois.
13. Jevtić, B. (2018). Olimpizam i studentski sport. U E. Kastratovic (ed): U duhu Olimpizma (str . 1547). Fakultet za biznis i pravo, Beograd.

14. Јевтић, Б. (2010). Систем спорта, спортски стручњаци и болоњски процес. У Г. Касум и сар (ед): Ангажованост наставно-научног кадра са акредитованих државних факултета спорта у оквиру активности националних спортских савеза и елтиних клубова и стручног кадра из националног спорта у систему образовања и усавршавања на акредитованим спортским државним образовним инстируцијама. стр.731. Факултет спорта и физичког васпитања и Министарство омладине и спорта., Београд.

15. Јевтић, Б. (2011). Систем спорта и дечији спорт. У Б. Јевтић, Ј. Радојевић, И. Јухас, Р. Ропрет (ед) Дечији спорт од праксе до академске области (стр 69-91). Факултет спорта и физичког васпитања, Београд.

16. Јевтић, Б. (2014) Спорт и предузетништво. Технологија, култура и развој, Зборник радова 21: 122-135, Удружење Технологија и развој, Београд.

17. Јевтић, Б. (2017). Научни часопис „Физичка култура“" у мисији развоја научне и друштвене заједнице. Физичка култура, 71 (2): 182-194

18. Копривица, Ч. (2018). Ното Maxinus. Елементи философије спорта. Укронија, Београд.

19. Lemyre,F., Trudel, P. \&Durand-Bush, N. (2007). How Youth-Sport Coaches Learn to Coach. The Sport Psychologist, 2007, 21, 191-209

20. Lyle, J. (2007). A review of the research evidence for the Impact of Coaching Education. International J. of Coaching Science, 1(1):19-36.

21. Malcom, D., Piementa, N., Pihheiro, C.M. (2014). Could and Should Coaching become Profession? Some Sociological Reflectiions. Int. J. of Sports SciఓCoaching, 1(1): 42-45. doi: 10.1123/sci. 20130017. 
22. McNamara, A., Button, A., Collins, D. (2010). The role of psychological characteristics in facilitating the pathway to elite performance. The Sport Psychologist 24: 52-73.

23. Moragas, M. (2006). Academic institutuins and Olympic movement. V Forum on Sport Education and Culture Forum by IOC undertaken. Beijing.

24. Parry, J. (2009). The etical and political values of the Olympic Movement. Etical and Political values of the Olympic Movement, Ghent

25. Petry, K., Froberg, K., Madella, A., Tokarski, W. (2008). Higer Education in Sport in Europe. Mayer\&Mayer (UK).

26. Радојевић,Ј., Јевтић, Б. (2011). Друштво и спорт деце и омладине. У Б. Јевтић, Ј. Радојевић, И. Јухас, Р. Ропрет (ед) Дечији спорт од праксе до академске области (стр 31-44). Факултет спорта и физичког васпитањ, Београд.

27. Scott, C.J. (2006 ). The mission of the University: Medieval to postmodern transformations. J. of Higher Education 77:1-39.

28. Sheridan, P.M. (2014). "Could and Should Sport Coaching Become a Profession? Some Sociological Reflections" A Commentary. International Sport Coaching Journal, 1: 46-49.

29. Smith, C.T.A.,Westerbeek, M.H. (2007). Sport as a vechile for deploying corporate social responsibility. The J. of Corporate Citizenship 25: 5-12.

30. Stoszkowski, J. \& Collins, D. (2015). Sources, topics and use of knowledge by coaches. Journal of Sport Science, 34(9):794-802.

31. Vocational education and training in the field of sport in the European Union: situation, trends and outlook. Vocaport (2004). EOSA, Lio

32. Šuput, D. (2015). Nastajanje sportskog prava Evropske unije. Strani Pravni Život, 2:99-115.

\section{Документа}

1. База квалификација у Републици Србији, http://noks.mps.gov.rs

2. Council of Europe (1992). European Sports Charter

3. European Commission (2007) White Paper on Sport

4. European Commission (2011) Developing the European dimension in sport

5. European Council (2000) Declaration on the Specific Characteristics of Sport and Its SocialFunction in Europe

6. European framework of qualification, www. cedefop.europe.eu

7. International Council for Coach Education. (2000). Magglingen Declaration

8. Номенклатура занимања у спорту. Министарство омладине и спорта, www.mos. gov.rs

9. United Nations (2000). Controbution of Sport to the Millennium development goals (www.un.org/ sport/sites/www.un.org.sport/files/documents/ $\mathrm{pdfs} /$ )

10. Закон о националном оквиру квалификација (2018). www.mpn.gov.rs

11. Закон о спорту (2016). Министарство омладине и спорта, www.mos.gov.rs 